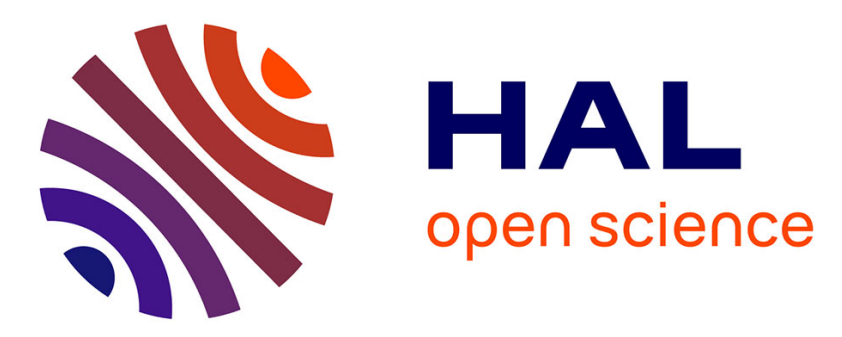

\title{
Marginal Perspectives: Sourcing Epi-Palaeolithic to Chalcolithic Obsidian from the Öküzini Cave (SW Turkey)
}

Tristan Carter, François-Xavier Le Bourdonnec, Metin Kartal, Gérard Poupeau, Thomas Calligaro, Philippe Moretto

\section{To cite this version:}

Tristan Carter, François-Xavier Le Bourdonnec, Metin Kartal, Gérard Poupeau, Thomas Calligaro, et al.. Marginal Perspectives: Sourcing Epi-Palaeolithic to Chalcolithic Obsidian from the Öküzini Cave (SW Turkey). Paléorient, 2011, 37 (2), pp.123 - 149. 10.3406/paleo.2011.5427 . hal-01743167

\section{HAL Id: hal-01743167 \\ https://hal.science/hal-01743167}

Submitted on 21 Dec 2018

HAL is a multi-disciplinary open access archive for the deposit and dissemination of scientific research documents, whether they are published or not. The documents may come from teaching and research institutions in France or abroad, or from public or private research centers.
L'archive ouverte pluridisciplinaire HAL, est destinée au dépôt et à la diffusion de documents scientifiques de niveau recherche, publiés ou non, émanant des établissements d'enseignement et de recherche français ou étrangers, des laboratoires publics ou privés. 


\title{
MARGINAL PERSPECTIVES: SOURCING EPI-PALAEOLITHIC TO CHALCOLITHIC OBSIDIAN FROM THE ÖKÜZINI CAVE (SW TURKEY)
}

\author{
T. Carter, F.-X. Le Bourdonnec, M. Kartal, G. Poupeau, T. Calligaro \\ and P. MORETTO
}

\begin{abstract}
Fifty-six pieces of obsidian from the Öküzini Cave in SW Anatolia were elementally characterised using particle induced $X$-ray emission [PIXE], the artefacts coming from strata that span the early Epi-Palaeolithic to Late Chalcolithic. The obsidian comes from two sources in southern Cappadocia, East Göllü Dă̆ and Nenezi Dăg (380 km distant), representing the earliest evidence for these sources' use at distance. The cave's inhabitants perpetually existed on the margins of those socio-economic networks responsible for the circulation of these central Anatolian resources, obsidian only rarely crossing the cultural boundaries that separated the cave's populations from their contemporaries in the Konya Plain and Cilicia.
\end{abstract}

\begin{abstract}
Résumé : La composition élémentaire de 56 pièces en obsidienne de la grotte d'Öküzini (sud-ouest de l'Anatolie), provenant des niveaux épipaléolithiques à chalcolithique, a été caractérisée par sonde nucléaire PIXE. Elle les rattache à deux sources cappadociennes, celles du Göllü Dă̆ Est et du Nenezi Dağ, distantes de 380 km; ce serait l'utilisation la plus ancienne jamais observée à une telle distance. Les habitants de la grotte d'Öküzini ont toujours été à la marge des réseaux socio-économiques responsables de la circulation des ressources anatoliennes. Ainsi, l'obsidienne n'a que rarement franchi les limites culturelles qui séparaient les occupants de cette grotte de leurs contemporains dans la plaine de Konya, et de la Cilicie.
\end{abstract}

Keywords: Obsidian sourcing; Öküzini Cave; Epi-Palaeolithic - Chalcolithic Anatolia; Exchange; Socio-economic frontiers. Mots-clés : Provenance; Obsidienne; Grotte d'Öküzini; Anatolie épi-paléolithique et chalcolithique; Échanges; Frontières socioéconomiques.

\section{INTRODUCTION}

Located in the foothills of the Katran Mountains, Öküzini is a small cave overlooking the alluvial plain of the Göksu River in south-western Turkey, $32 \mathrm{~km} \mathrm{NW}$ of modern Antalya and the current Mediterranean coastline (fig. 1). While first investigated between 1956-1965 and again in 1989, ${ }^{1}$ the material discussed here comes from the 1989-1998 excavations undertaken by an international team directed by Professors

1. Kökten, 1963; Albrecht, 1991; Albrecht et al., 1992.
Işin Yalçınkaya and Marcel Otte. ${ }^{2}$ Most of the cave's occupation relates to the Epi-Palaeolithic, after which there is material relating to the Neolithic, Chalcolithic and Roman periods in the uppermost strata. ${ }^{3}$ The Öküzini Cave thus provides a detailed sequence of Late Pleistocene and Early Holocene human activity in the region, with radiocarbon dates spanning the $19^{\text {th }}-4^{\text {th }}$ millennia cal. BC and into the historic period (table 1). ${ }^{4}$

\footnotetext{
2. Yalçınkaya et al., 2002.

3. López Bayón, Léotard et Kartal, 2002.

4. López Bayón et al., 2002.
} 


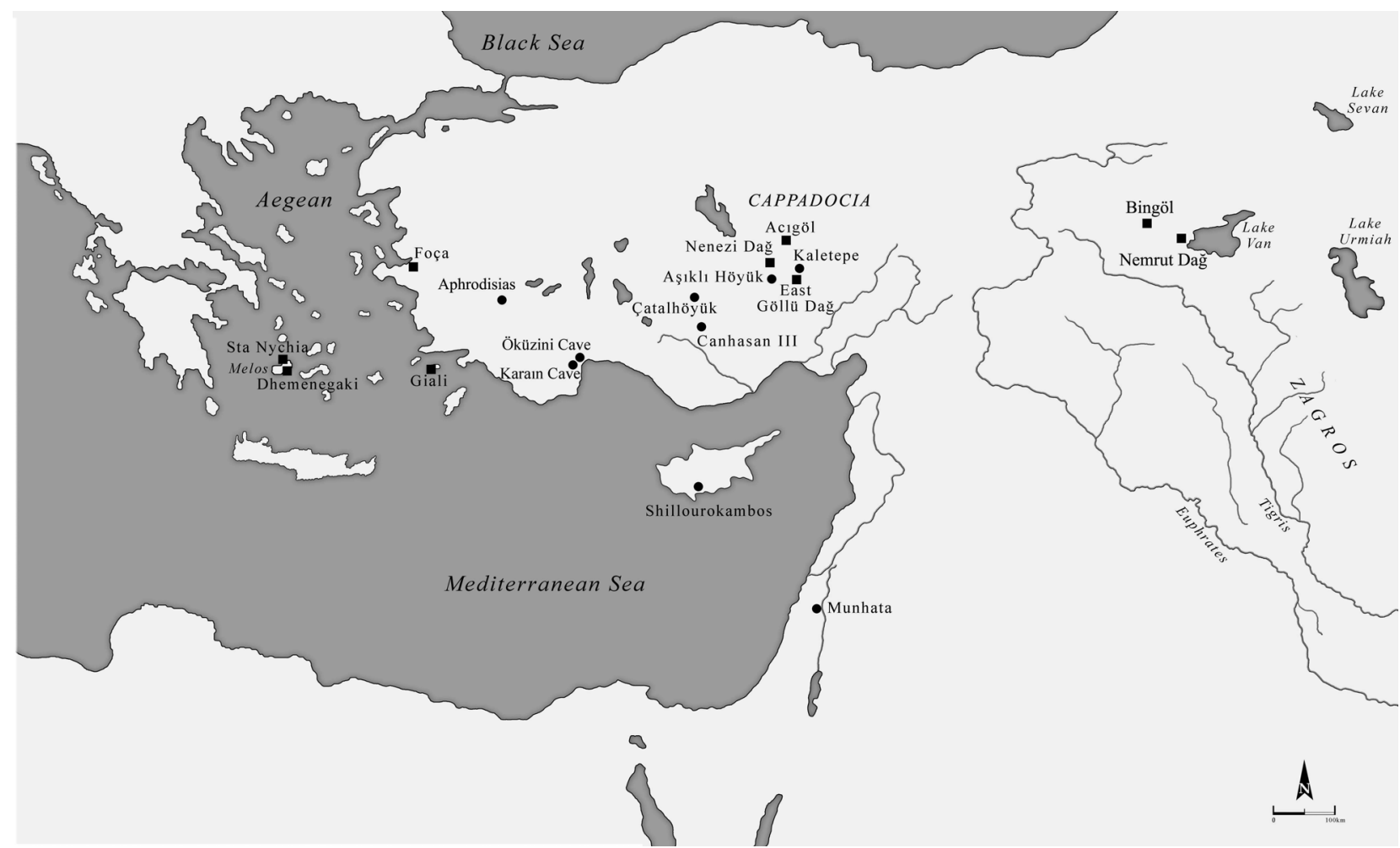

Fig. 1 - The main sites and obsidian sources referenced in the text (M. Milić).

Table 1 - The main chronological schemes for the Öküzini Cave occupation sequence and the quantity of obsidian within each sub-phase.

\begin{tabular}{|c|c|c|c|c|c|}
\hline Geo. Horizon & Phase & Climate & Period & Approximate Dates & Obsidian \\
\hline 0 & $\mathrm{VI}$ & Early - Middle Holocene & Early - Late Chalcolithic & $5^{\text {th }}-4^{\text {th }}$ millennia cal BC & $29(3.67 \mathrm{~g})$ \\
\hline $\mathrm{lb} 1$ & $\mathrm{VI}$ & Early Holocene & Late Pottery Neolithic & $7^{\text {th }}$ millennium cal BC & $23(5.47 \mathrm{~g})$ \\
\hline la1 & $\mathrm{V}$ & Younger Dryas & late Epi-Palaeolithic & $11^{\text {th }}-10^{\text {th }}$ millennia cal $B C$ & uncertain \\
\hline la2 & $\mathrm{V}$ & Younger Dryas & late Epi-Palaeolithic & $12^{\text {th }}$ millennium cal BC & $3(0.16 \mathrm{~g})$ \\
\hline \multicolumn{6}{|c|}{ Hiatus } \\
\hline II & IV & Older Dryas/ Bölling & late Epi-Palaeolithic & $13^{\text {th }}-12^{\text {th }}$ millennia cal BC & - \\
\hline III & III & Bölling & late Epi-Palaeolithic & $13^{\text {th }}$ millennium cal BC & - \\
\hline III-IV & III & Bölling & late Epi-Palaeolithic & no dates & - \\
\hline IV & III & Bölling & late Epi-Palaeolithic & $13^{\text {th }}$ millennium cal BC & - \\
\hline V & III & Bölling & late Epi-Palaeolithic & no dates & - \\
\hline $\mathrm{V}-\mathrm{VI}$ & III & Bölling & late Epi-Palaeolithic & no dates & - \\
\hline Vla & III & Bölling & late Epi-Palaeolithic & no dates & - \\
\hline Vla-Vlb & III & Bölling & late Epi-Palaeolithic & $14^{\text {th }}-13^{\text {th }}$ millennia cal BC & - \\
\hline $\mathrm{Vlb}$ & III & Bölling & late Epi-Palaeolithic & $15^{\text {th }}-13^{\text {th }}$ millennia cal BC & - \\
\hline VI-VII & III & Bölling & late Epi-Palaeolithic & $16^{\text {th }}-15^{\text {th }}$ millennia cal BC & - \\
\hline \multicolumn{6}{|c|}{ Hiatus } \\
\hline VII & II & Warm Phase & early Epi-Palaeolithic & $16^{\text {th }}$ millennium cal BC & - \\
\hline VII-VIII & II & Warm Phase & early Epi-Palaeolithic & $16^{\text {th }}$ millennium cal BC & - \\
\hline VIII & II & Warm Phase & early Epi-Palaeolithic & $17^{\text {th }}-16^{\text {th }}$ millennia cal BC & $1(0.28 \mathrm{~g})$ \\
\hline IX & II & Late Glacial Maximum & early Epi-Palaeolithic & $17^{\text {th }}$ millennium cal BC & - \\
\hline \multicolumn{6}{|c|}{ Hiatus } \\
\hline $\mathrm{x}$ & 1 & Late Glacial Maximum & early Epi-Palaeolithic & $19^{\text {th }}-18^{\text {th }}$ millennia cal BC & - \\
\hline $\mathrm{XI}$ & 1 & Late Glacial Maximum & early Epi-Palaeolithic & $19^{\text {th }}-18^{\text {th }}$ millennia cal BC & - \\
\hline XII & 1 & Late Glacial Maximum & early Epi-Palaeolithic & $19^{\text {th }}-18^{\text {th }}$ millennia cal BC & - \\
\hline
\end{tabular}




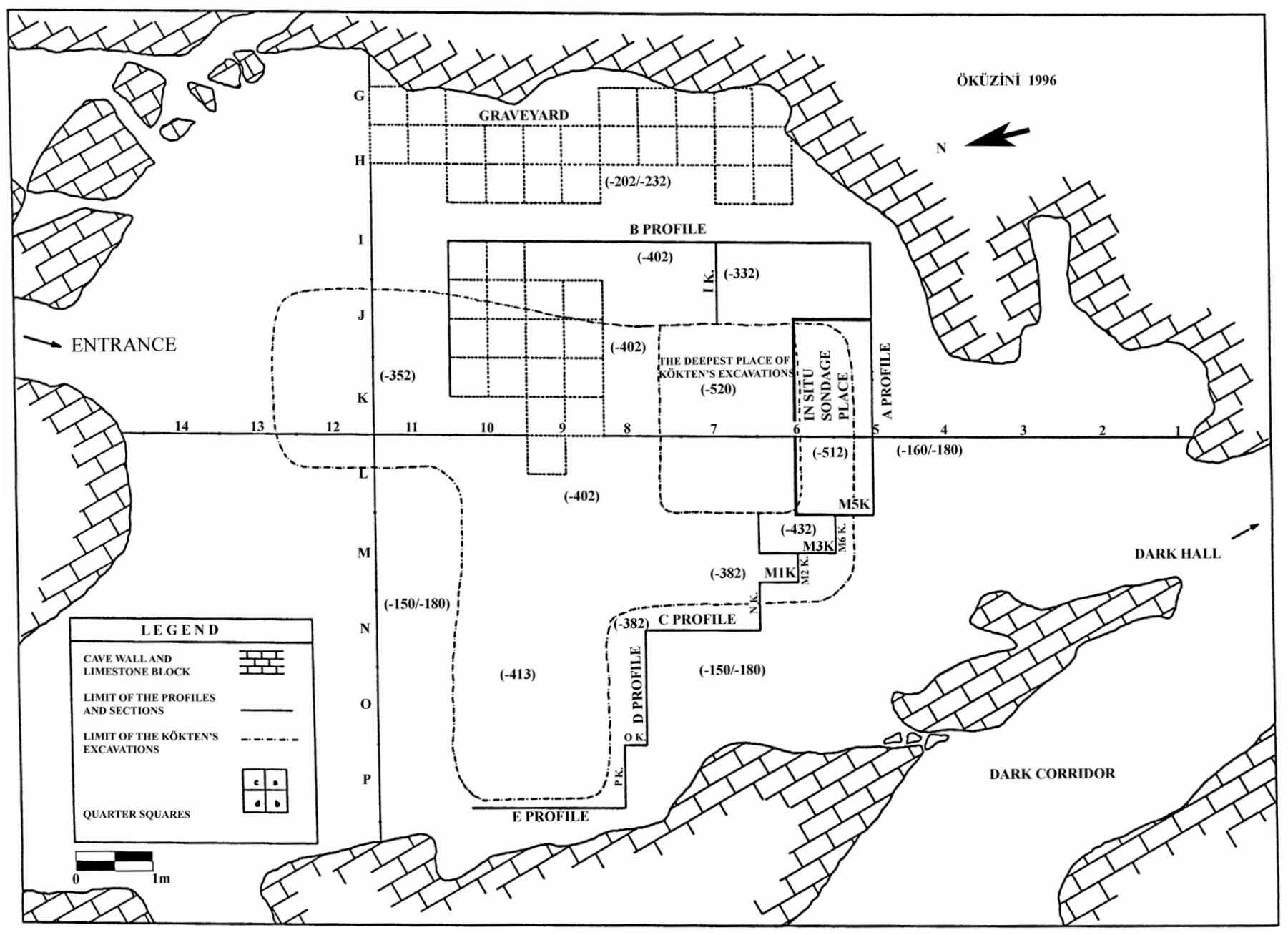

Fig. 2 - Plan of the Öküzini Cave and excavation trenches (from OTTE et al., 2003: fig. 2).

The faunal data indicate that during the early EpiPalaeolithic the cave acted as a late spring-early autumn base for hunting wild goat, sheep and fallow deer, most of which were likely procured within a $10 \mathrm{~km}$ radius. ${ }^{5}$ Following a period of abandonment, the cave later experienced more frequent and lengthier uses over the summer months, a "trajectory of increasing sedentism" that continued into the later Epi-Palaeolithic. ${ }^{6}$ Throughout these periods the cave's occupants supplemented their diets by foraging a wide range of wild fruits, nuts, roots, bulbs and tubers. ${ }^{7}$

The site also produced a small amount of parietal and mobiliary art, with aurochs incised on the cave wall and a series of limestone pebbles inscribed with complex geometric designs. ${ }^{8}$ These symbols provide links to iconography from late Upper Palaeolithic Western Europe and the early EpiPalaeolithic Levant. ${ }^{9}$ More immediately, the Öküzini Cave material forms part of an Antalya-region artistic repertoire, with carved images from contemporary levels at nearby Karain Cave (1.5 km away [fig. 1]).

The most recent strata contained mixed deposits of Late Ceramic Neolithic and Early Chalcolithic date (the latter including burials), followed by traces of Roman and more recent activity (fig. 2 and table 1).

8. Marshack, 2002; Otte et al., 1995: 941-943.

9. Marshack, 2002: 285.

5. Atici and Stutz, 2002; Martinoli, 2004: 76-77.

6. Atici and Stutz, 2002: 105.

7. Martinoli, 2004. 


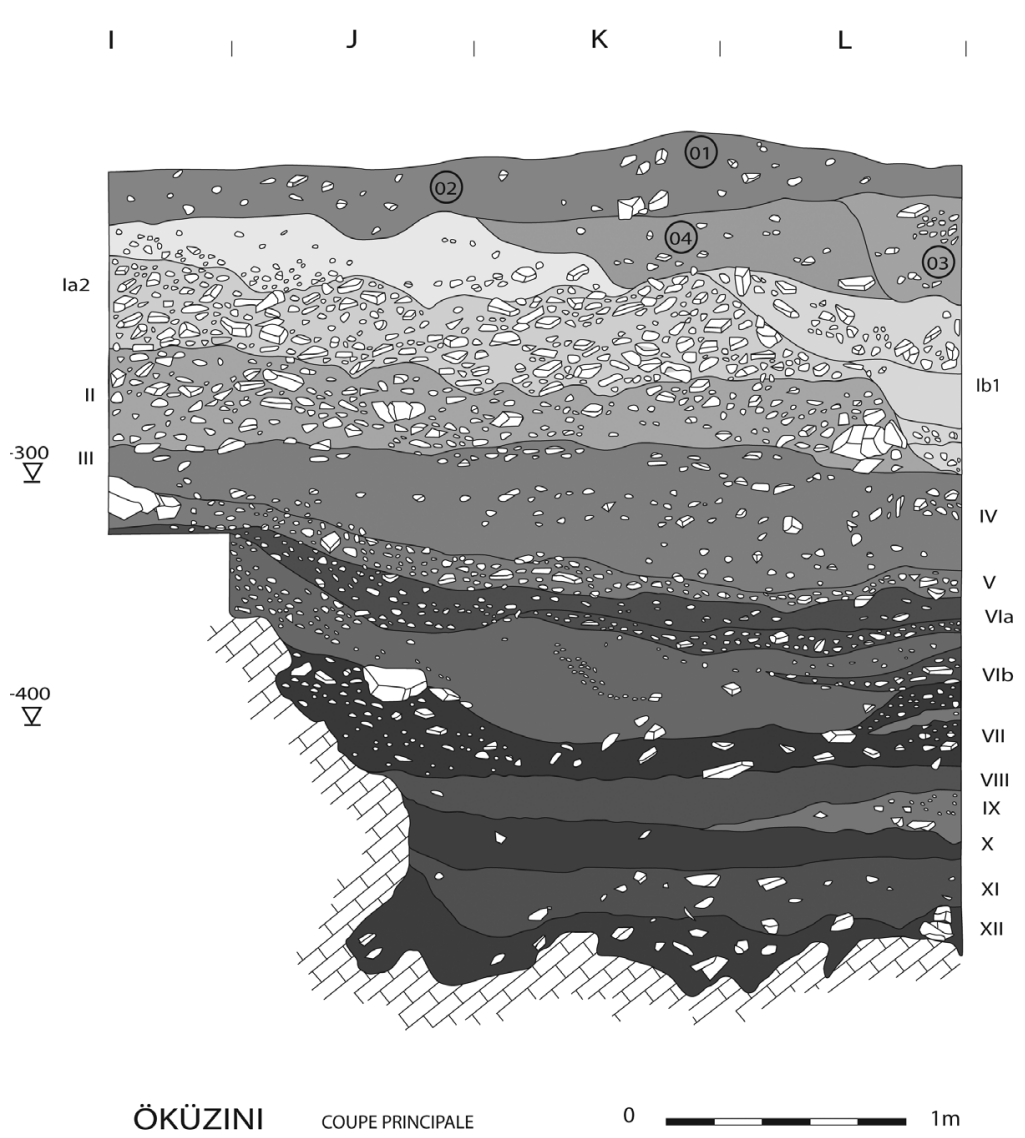

Fig. 3 - Öküzini Cave South or Main Profile (from LÓPEZ BAYÓN et al., 2002: fig. 3a).

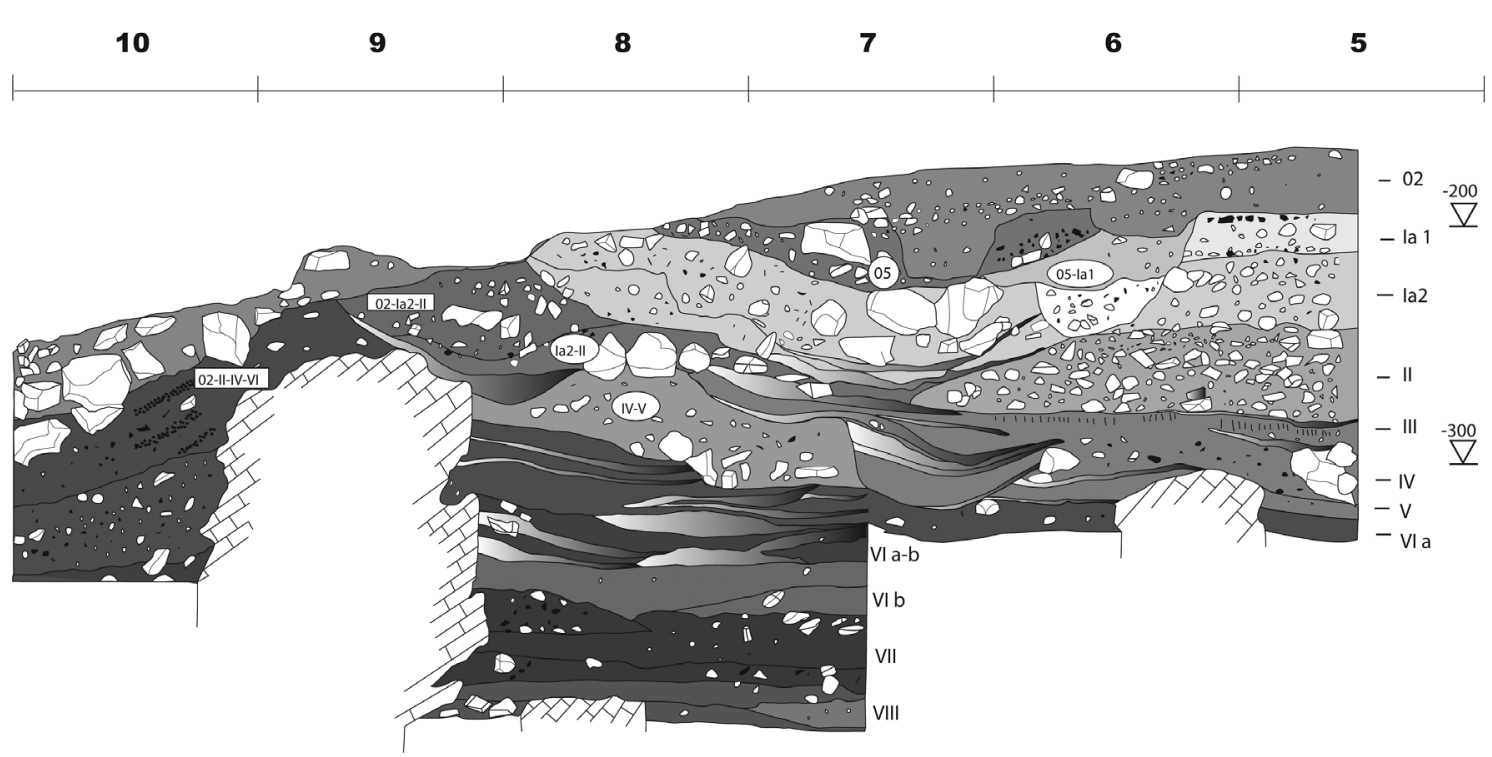

ÖKÜZINI

Fig. 4 - Öküzini Cave East or Secondary Profile (from LÓPEZ BAYÓN et al., 2002: fig. 3b). 
Table 2 - Radiocarbon dates for Geological Horizons with obsidian. Labs: ETH = Zurich; GX = Krueger Enterprises, Cambridge, USA; HD = Heidelberg, Germany; Lv = Louvain, Belgium; OxA = Oxford, UK; RT = Weizmann Institute, Israel (data from GOLDBERG and BAR-YOSEF, 2002: Table 3; KARTAL and EREK, 2002: table 2; LÓPEZ BAYÓN et al., 2002: table 1; OTTE et al., 2003).

\begin{tabular}{|c|c|c|c|c|c|}
\hline Square / $\mathrm{AH}$ & GH & Sample & Lab No. & Date uncal BP & Date cal BC (confidence) \\
\hline G11b-d/5 - Grave V & 0 & bone & RT-3897 (AA43929) & $5,965 \pm 125$ & $4838-4807$ \\
\hline G7b-d/5 - Grave III & 0 & bone & RT-3896 (AA43928) & $4,890 \pm 45$ & 3657 \\
\hline H7b/4 - Grave III & 0 & charcoal & RT-3891 & $4,745 \pm 55$ & $3,624-3,524$ \\
\hline H7b/3 - Grave II & 0 & charcoal & RT-3892 & $4,465 \pm 55$ & $3,257-3,098$ \\
\hline I5c/3 - Grave I & 0 & charcoal & RT-3899 & $5,430 \pm 40$ & $4,326-4,256$ \\
\hline $\mathrm{L} 5 / 2$ & O3-O4-la1-lb1 & charcoal & HD-13363-13884 & $8595 \pm 90$ & $7740-7540(1 \sigma 68.2 \%)$ \\
\hline L5/6 & la2-Ib1-II & charcoal & ETH-8026 & $12,020 \pm 90$ & $12,400-11,850(1 \sigma 68.2 \%)$ \\
\hline $\mathrm{K} 5 \mathrm{c} / 5$ & la2 & charcoal & RT-1441 & $10,440 \pm 115$ & $10,550-10,255(1 \sigma 68.2 \%)$ \\
\hline $\mathrm{K} 5 \mathrm{c} / 6-7$ & la2 & bone & GX-16283 & $11,880 \pm 530$ & $12,500-11,200(1 \sigma 58.7 \%)$ \\
\hline L5/4 & la2-lb1 & charcoal & ETH-8032 & $11,730 \pm 90$ & $11,770-11,530(1 \sigma 52.4 \%)$ \\
\hline $\mathrm{K} 5 \mathrm{c} / 6$ & la2 & bone & Lv-1895 (b) & $11,440 \pm 110$ & $11,540-11,230(1 \sigma 68.2 \%)$ \\
\hline $\mathrm{K} 5 \mathrm{c} / 5$ & la1-la2 & charcoal & RT-1441 & $10,440 \pm 115$ & $10,700-10,150(1 \sigma 63.1 \%)$ \\
\hline $\mathrm{L} 5 / 5$ & la2-Ib1 & charcoal & HD-13364-13887 & $9,650 \pm 50$ & $9,220-9,110(1 \sigma 38.4 \%)$ \\
\hline $18 \mathrm{~b} / 8$ & la1-la2-II & charcoal & OxA-5213 & $10,150 \pm 90$ & $10,150-9,400(1 \sigma 68.2 \%)$ \\
\hline L5/3 & la2-Ib1 & charcoal & ETH-8031 & $8,800 \pm 80$ & $8,200-7,650(1 \sigma 68.2 \%)$ \\
\hline L5c/25 & VIII & bone & Lv-1999 (b) & $13,620 \pm 280$ & $14,750-14,050(1 \sigma 68.2 \%)$ \\
\hline $\mathrm{K} 5 \mathrm{~d} / 25$ & VIII & charcoal & OxA-5176 & $14,820 \pm 150$ & $16,100-15,450(1 \sigma 68.2 \%)$ \\
\hline $18 \mathrm{~b} / 22$ & VIII & charcoal & OxA-5225 & $14,940 \pm 140$ & $16,250-15,600(1 \sigma 68.2 \%)$ \\
\hline $18 \mathrm{~d} / 21$ & VIII & bone & Lv-2081 (b) & $13,910 \pm 120$ & $15,050-14,450(1 \sigma 68.2 \%)$ \\
\hline $17 \mathrm{~d} / 21$ & VIII & bone & Lv-2077 (b) & $14,380 \pm 190$ & $15,650-14,950(1 \sigma 68.2 \%)$ \\
\hline 18 & VIII & charcoal & RT-2334 & $13,670 \pm 175$ & $14,800-14,150(1 \sigma 68.2 \%)$ \\
\hline
\end{tabular}

\section{RELATIVE AND ABSOLUTE DATING}

Stratigraphically, the Öküzini Cave deposits were excavated as a number of arbitrary 'archaeological horizons' [AH], from $\mathrm{AH} 1$ at the top, to AH 33 at the base of the sequence. Given that many of the anthropomorphic deposits were sloping, these horizons ultimately incorporated more than one stratigraphic level and materials of differing dates..$^{10}$ Subsequent sedimentary and climatic studies allowed the excavators to rework these arbitrary strata into six geo-climatic phases spanning the Glacial Maximum to the Holocene. These six phases were in turn sub-divided into 13 geological horizons [GH], with the cave's uppermost level labelled 0 and the basal deposits labelled XII (fig. 3-4). ${ }^{11}$ This relative sequence, in conjunction with material culture studies and 67 radiocarbon determinations, was then employed to create a six-phase cultural phasing for the cave, with Phase I the earliest and Phase VI the latest. ${ }^{12}$

10. López Bayón et al., 2002: 50.

11. López Bayón, Léotard et Kartal, 2002.

12. Goldberg and Bar-Yosef, 2002; Kartal and Erek, 2002: table 3; López Bayón et al., 2002: table 1; Otte et al., 2003.
A summary of these various schemes is presented in table 1, while the absolute dates for those horizons containing obsidian are discussed in more detail below (see also table 2).

\section{THE ÖKÜZINI CAVE OBSIDIAN}

Throughout the occupation the chipped stone assemblages were dominated by local flint and radiolarites procured from the banks of the Göksu and Burhan rivers $20 \mathrm{~km}$ to the southwest. ${ }^{13}$ The material also includes small quantities of quartz and obsidian, the latter recovered primarily from Neolithic/ Chalcolithic strata though a handful are recorded from EpiPalaeolithic deposits (table 1). Given that the closest sources are located over $300 \mathrm{~km}$ away (fig. 1), the Öküzini Cave obsidian provides a small but important data-set with which to investigate the early long-distance movement of this resource. The material further allows us to comment on the mobility and

13. Léotard et López Bayón, 2002: 189-190, fig. 27-28; Pawlikowski, 2002. 

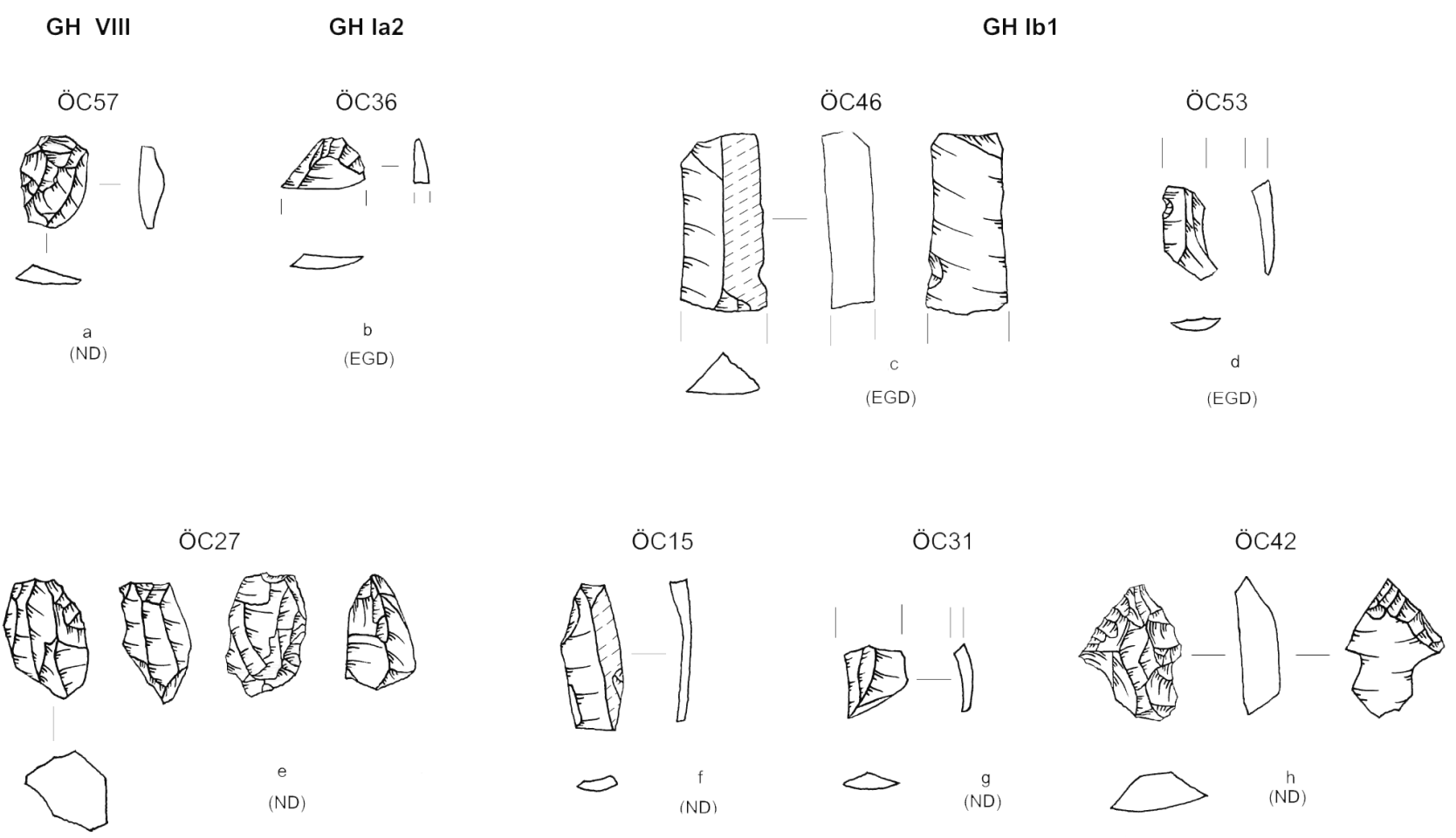

GH 0
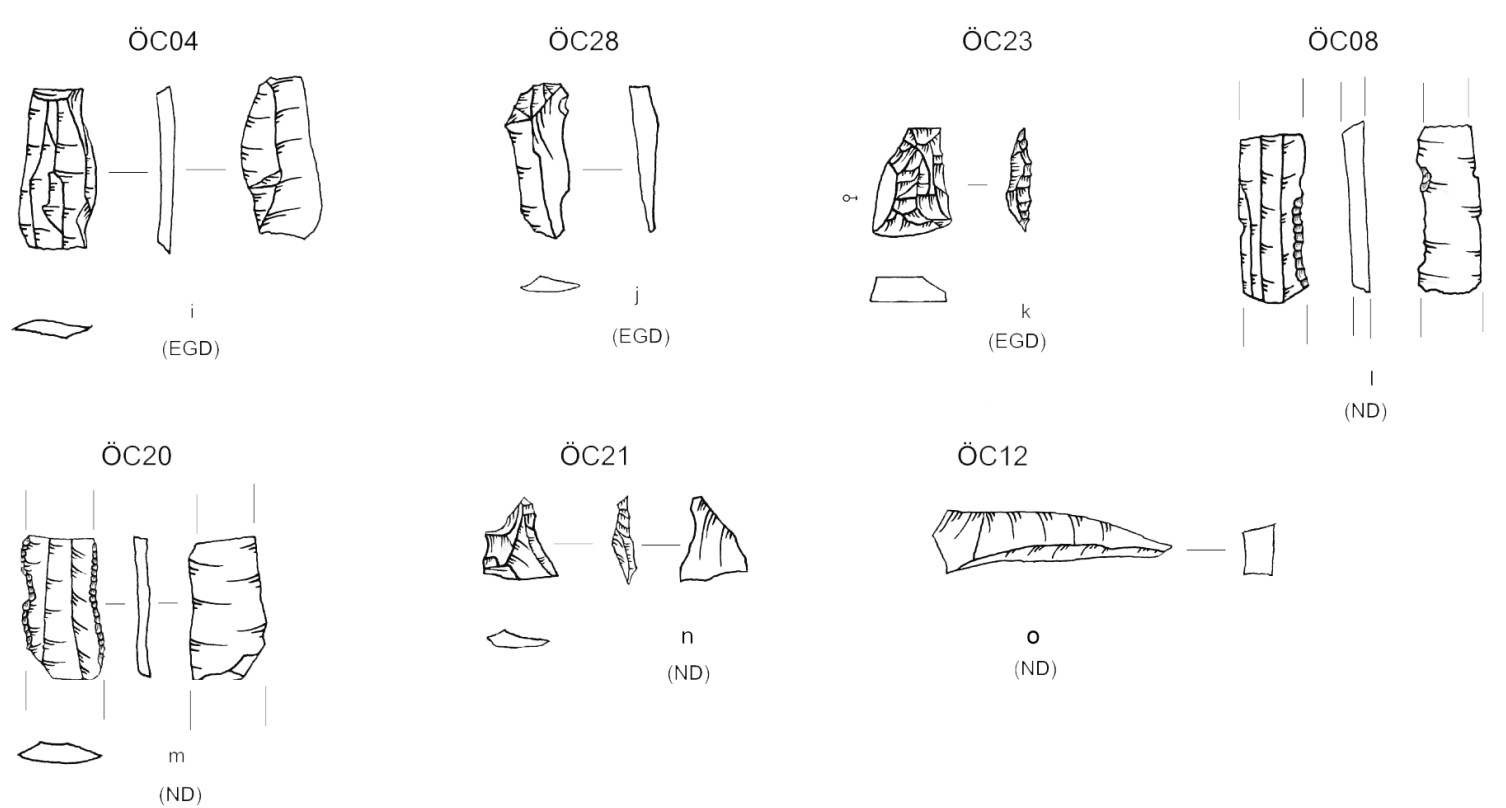

ÖC12
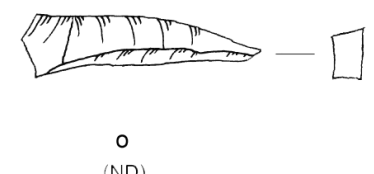

(ND)

Fig. 5 - Diagnostic obsidian artefacts from the Öküzini Cave by Geological Horizon and source (D. Mihailović). 
contacts of the cave's inhabitants through time and helps us to fill something of a regional gap in obsidian sourcing studies, with precious little work having been previously undertaken in this part of Anatolia. ${ }^{14}$

This paper represents the first detailed study of the Öküzini Cave obsidian, as most of the artefacts come from assemblages other than those sampled for detailed analyses by the excavators (their "unités d'étude"). ${ }^{15}$ The material comprises a mere 56 pieces ( $10.52 \mathrm{~g}$ in total) mainly in the form of tiny noncortical flakes recovered from the heavy residue sample of the water-sieving process (fig. 5-6 and table 3). Obsidian thus represents a tiny proportion of the Öküzini Cave chipped stone, less than $0.1 \%$ of the raw materials in any one period. This fact has to be borne in mind when we come to consider the material's socio-economic significance, as such a small assemblage cannot bear too much interpretative weight.

\section{DESIGNING THE ÖKÜZINI CAVE SOURCING STUDY}

Sourcing the Öküzini Cave obsidian involves two stages. The first is to elementally characterize the objects; the second is to match the artefacts chemical signature with that of known geological sources. First we consider the sources that are most likely to have been exploited by the inhabitants of the Öküzini Cave, based on the following factors: 1) which archaeologically significant obsidian sources are closest to the site; 2) the results of previous obsidian characterisation studies on nearby (ideally contemporary) assemblages; 3) the artefacts date; 4) other lines of evidence that shed light on the cave occupants' geographical spheres of interaction / contact (via faunal, archaeobotanical, or material culture studies inter alia).

\section{SITE LOCATION}

In terms of linear distance, the Aegean / western Anatolian sources of Giali and Foça are the nearest to the Öküzini Cave at 310 and $370 \mathrm{~km}$ respectively (fig. 1). Neither case seems a likely candidate, with precious little evidence for the use of the former, ${ }^{16}$ while most of the Giali products are spherulitic (and

14. Cf. Chataigner, 1998; Cauvin et Chataigner, 1998. 15. Kartal, 2002; Kösem, 2002; Léotard et López Bayón, 2002: 111. 16. Poidevin, $1998: 110$.
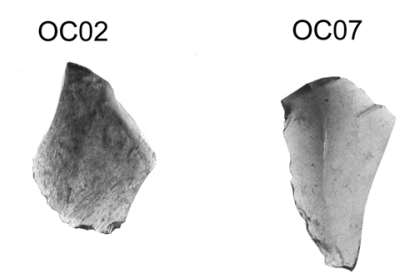

OC10
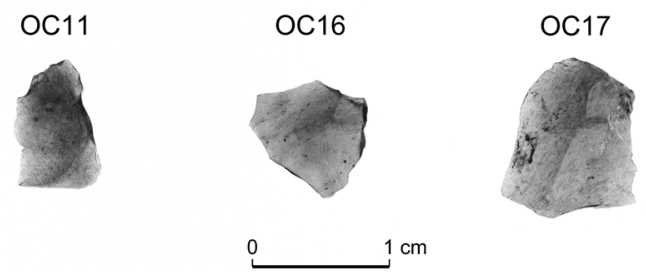

Fig. 6 - A representative sample of small obsidian blanks from the Öküzini Cave (F.-X. Le Bourdonnec).

thus visually distinctive), their use seemingly restricted to populations on the nearby Aegean islands and western Anatolia. ${ }^{17}$ The next closest sources are located in southern Cappadocia (ca $380 \mathrm{~km}$ distant), with East Göllü Dağ and Nenezi Dağ the most likely candidates, being the main obsidians procured by Epi-Palaeolithic - Neolithic communities in central Anatolia, Cyprus and the Levant. ${ }^{18}$ Returning to the Aegean, we have the well-known sources of Sta Nychia and Dhemenegaki on the Cycladic island of Melos, $c a 540 \mathrm{~km}$ from the Öküzini Cave, ${ }^{19}$ whose products are known to have been exploited from at least the early $11^{\text {th }}$ millennium cal. BC (Aegean Upper Palaeolithic) ${ }^{20}$ Moreover, small quantities of these raw materials are attested in Anatolia, ${ }^{21}$ albeit no furthest east than Early Chalcolithic Aphrodisias (Caria), $175 \mathrm{~km}$ north-west of the Öküzini Cave (fig. 1). ${ }^{22}$

\section{PREVIOUS ANALYSES}

This is the second characterisation study involving obsidian from the Öküzini Cave, as one artefact from the 1950's excavations was included in the first sourcing project to be undertaken

17. Georgiadis, 2008.

18. Chataigner, 1998; Poidevin, 1998.

19. Renfrew et al., 1966; Torrence, 1986.

20. Perlès, 1987 : 142-145.

21. Carter, 2009: 207.

22. Blackman, 1986. The alleged piece from Late Neolithic Hacılar in the Lake District (only $70 \mathrm{~km}$ away [Gale, 1981: 49]), has since been assigned a Cappadocian source (Renfrew and Aspinall, 1990: 270). 
Table 3 - Contextual details, techno-typological attributes and raw material source for the 56 obsidian artefacts from the Öküzini Cave. (measurements in $\mathrm{cm}$, weight in $\mathrm{g}$; state: $P$ (proximal), $M$ (medial), D (distal), W (whole)).

\begin{tabular}{|c|c|c|c|c|c|c|c|c|c|c|c|c|c|}
\hline Sample & Trench & AH & GH & Date & Source & Artefact & State & Cortex & L & w & Th & Use & Wgt \\
\hline OC 01 & $15 \mathrm{~d}$ & 0 & $\mathrm{GH} 0$ & Chalco / mix & EGD & Bladelet & $\mathrm{P}$ & 0 & 0,93 & 0,98 & 0,21 & Yes & 0,26 \\
\hline OC 02 & G8d & $0-1$ & $\mathrm{GHO}$ & Chalco / mix & EGD & Flake & D & 0 & 0,59 & 0,41 & 0,22 & No & 0,05 \\
\hline OC 03 & J5d & 1 & $\mathrm{GHO}$ & Chalco / mix & EGD & Flake & $P$ & 0 & 0,26 & 0,41 & 0,03 & No & 0,01 \\
\hline OC 04 & $16 \mathrm{~b}$ & 1 & GHO 0 & Chalco / mix & EGD & Bladelet & D & 0 & 1,93 & 0,91 & 0,19 & Yes & 0,43 \\
\hline OC 05 & J5c & 1 & $\mathrm{GHO}$ & Chalco / mix & ND & Flake & M & 0 & 0,34 & $\begin{array}{ll}0,38 \\
\end{array}$ & 0,13 & No & 0,04 \\
\hline OC 06 & 18c & $1-2$ & $\mathrm{GH} 0$ & Chalco / mix & $\mathrm{ND}$ & Bladelet & M & 0 & 0,87 & 0,46 & 0,09 & No & 0,04 \\
\hline OC 07 & H8d & $1-2$ & GH 0 & Chalco / mix & $\mathrm{ND}$ & Flake & $\mathrm{D}$ & 0 & 0,74 & 0,4 & 0,03 & No & 0,03 \\
\hline OC 08 & $\mathrm{H} 7 \mathrm{~b}$ & 2 & $\mathrm{GHO}$ & Chalco / mix & $\mathrm{ND}$ & Bladelet (retouch) & M & 0 & 2 & 0,74 & 0,17 & Yes & 0,38 \\
\hline OC 10 & $17 a$ & 2 & $\mathrm{GHO}$ & Chalco / mix & EGD & Flake & W & 0 & 0,42 & 0,29 & 0,06 & No & 0,01 \\
\hline OC 11 & $17 a$ & 2 & $\mathrm{GHO}$ & Chalco / mix & ND & Flake & M & 0 & 0,52 & 0,24 & 0,08 & No & 0,01 \\
\hline OC 12 & $17 a$ & 2 & GH 0 & Chalco / mix & $\mathrm{ND}$ & Sliver / flake & M & 0 & 0,69 & 2,76 & 0,41 & No & 0,74 \\
\hline OC 13 & $17 a$ & 2 & $\mathrm{GHO}$ & Chalco / mix & ND & Trapeze on blade & M & 0 & 0,67 & 0,8 & 0,16 & Yes & 0,09 \\
\hline OC 14 & $18 a$ & 2 & $\mathrm{GHO}$ & Chalco / mix & EGD & Flake & $P$ & 0 & 0,87 & 0,56 & 0,12 & No & 0,06 \\
\hline OC 16 & $\mathrm{H} 7 \mathrm{~d}$ & 3 & GH 0 & LCh (Grave II) & ND & Flake & $M$ & 0 & 0,36 & 0,44 & 0,07 & No & 0,01 \\
\hline OC 17 & H8a & 3 & $\mathrm{GHO}$ & Chalco / mix & EGD & Bladelet & $\mathrm{P}$ & 0 & 0,63 & 0,46 & 0,16 & No & 0,04 \\
\hline OC 18 & H8b & 3 & $\mathrm{GHO}$ & Chalco / mix & EGD & Flake & $\mathrm{P}$ & 0 & 0,76 & 0,66 & 0,08 & No & 0,03 \\
\hline OC 19 & H8b & 3 & $\mathrm{GHO}$ & Chalco / mix & ND & Flake (dull) & $P$ & 0 & 0,85 & 0,86 & 0,26 & No & 0,14 \\
\hline OC 20 & $\mathrm{H} 8 \mathrm{c}$ & 3 & $\mathrm{GHO}$ & Chalco / mix & $\mathrm{ND}$ & Bladelet (notch / retouch) & M & 0 & 1,74 & 0,89 & 0,18 & Yes & 0,42 \\
\hline OC 21 & $\mathrm{H} 9 \mathrm{~b}$ & 3 & GH 0 & Chalco / mix & ND & Bladelet & M & 0 & 1,06 & 0,79 & 0,25 & Yes & 0,14 \\
\hline OC 22 & $\mathrm{H} 9 \mathrm{~b}$ & 3 & GH 0 & Chalco / mix & ND & Flake & $\mathrm{P}$ & 0 & 0,66 & 0,41 & 0,09 & No & 0,03 \\
\hline OC 23 & $\mathrm{H} 9 \mathrm{~b}$ & 3 & $\mathrm{GH} 0$ & Chalco / mix & EGD & Trapeze on blade & M & 0 & 0,88 & 1,29 & 0,3 & No & 0,30 \\
\hline OC 24 & $\mathrm{H} 10 \mathrm{~b}$ & 3 & $\mathrm{GHO}$ & Chalco / mix & $\mathrm{ND}$ & Flake & $\mathrm{D}$ & 0 & 0,65 & 0,37 & 0,08 & No & 0,02 \\
\hline OC 25 & $\mathrm{H} 12 \mathrm{c}$ & 3 & GHO & Chalco / mix & EGD & Flake & $\mathrm{D}$ & 0 & 0,57 & 0,46 & 0,14 & No & 0,03 \\
\hline OC 28 & $17 \mathrm{c}$ & 3 & $\mathrm{GHO}$ & Chalco / mix & EGD & Bladelet & PW & 0 & 1,86 & 0,69 & 0,21 & Yes & 0,24 \\
\hline OC 29 & G7d & 4 & $\mathrm{GH} 0$ & Chalco / mix & ND & Flake & M & 0 & 0,67 & 0,62 & 0,19 & Yes & 0,09 \\
\hline OC 34 & $\mathrm{H} 13 \mathrm{a}$ & 4 & $\mathrm{GHO}$ & Chalco / mix & ND & Flake & $\mathrm{D}$ & 0 & 0,61 & 0,51 & 0,08 & No & 0,03 \\
\hline OC 32 & $\mathrm{H} 12 \mathrm{a}$ & 4 & GH 0-I & LN/ ECh & ND & Flake & M & 0 & 0,27 & 0,49 & 0,06 & No & 0,01 \\
\hline OC 33 & $\mathrm{H} 12 \mathrm{~d}$ & 4 & GH 0-I & LN / ECh & $\mathrm{ND}$ & Flake & $\mathrm{D}$ & 0 & 0,33 & 0,41 & 0,1 & No & 0,01 \\
\hline OC 56 & 112a & 5 & GH 0-I & LN/ECh & EGD & Flake & D & 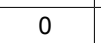 & 0,7 & 0,36 & 0,09 & No & 0,02 \\
\hline OC 09 & 16c & 2 & GH Ib1 & LN / Ech (pit) & ND & Flake & D & -5 & 0,81 & 0,41 & 0,22 & es & 0,05 \\
\hline OC 30 & H8a & 4 & GH Ib1+D64 & LN / Ech (pit) & EGD & Bladelet & M & 0 & 0,91 & 0,62 & 0,13 & Yes & 0,11 \\
\hline OC 41 & $\mathrm{H} 10 \mathrm{~b}$ & 5 & GH Ib1 & LN / Ech (pit) & ND & Flake & D & 2 & 0,4 & 0,37 & 0,12 & No & 0,02 \\
\hline OC 42 & $\mathrm{H} 10 \mathrm{~d}$ & 5 & GH Ib1 & LN / Ech (pit) & $\mathrm{ND}$ & 3arb/tang point on blade & $\mathrm{M}$ ? & 0 & 1,88 & 1,33 & 0,45 & Yes & 0,98 \\
\hline OC 43 & $\mathrm{H} 11 \mathrm{~b}$ & 5 & GH Ib1 & LN / Ech (pit) & ND & Flake & $\mathrm{D}$ & $m^{2}$ & 0,28 & 0,51 & 0,05 & No & 0,01 \\
\hline OC 44 & $\mathrm{H} 11 \mathrm{c}$ & 5 & GH Ib1 & LN / Ech (pit) & EGD & Bladelet & $M$ & 0 & 0,19 & 0,49 & 0,12 & No & 0,02 \\
\hline OC 45 & $\mathrm{H} 11 \mathrm{c}$ & 5 & GH Ib1 & LN / Ech (pit) & $\mathrm{ND}$ & Flake & $\mathrm{D}$ & 0 & 0,27 & 0,22 & 0,04 & No & 0,00 \\
\hline OC 46 & H11d & 5 & GH Ib1 & LN / Ech (pit) & EGD & polar blac & M & 50 & 2,41 & 1,13 & 0,53 & Yes & 1,63 \\
\hline OC 47 & $\mathrm{H} 12 \mathrm{~b}$ & 5 & GH Ib1 & LN / Ech (pit) & $\mathrm{D}$ & Flake & $\mathrm{D}$ & 0 & 0,76 & 0,44 & 0,09 & No & 0,04 \\
\hline OC 48 & $\mathrm{H} 12 \mathrm{~b}$ & 5 & GH Ib1 & LN / Ech (pit) & ND & Flake & W & 0 & 0,29 & 0,65 & 0,03 & No & 0,02 \\
\hline OC 50 & $\mathrm{H} 12 \mathrm{~b}$ & 5 & GH Ib1 & LN / Ech (pit) & 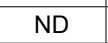 & Flake & $\mathrm{D}$ & $N^{2}$ & 0,2 & 0,19 & 0,02 & No & 0,00 \\
\hline OC 51 & $\mathrm{H} 12 \mathrm{~b}$ & 5 & GH Ib1 & LN / Ech (pit) & EGD & Flake & $\mathrm{D}$ & 0 & 0,09 & 0,62 & 0,12 & No & 0,02 \\
\hline OC 52 & $\mathrm{H} 12 \mathrm{~b}$ & 5 & GH Ib1 & LN / Ech (pit) & EGD & Flake & $\mathrm{w}$ & $\mathrm{C}^{2}$ & 0,31 & 0,29 & 0,01 & No & 0,01 \\
\hline OC 53 & $\mathrm{H} 13 \mathrm{a}$ & 5 & GH Ib1 & LN / Ech (pit) & EGD & Bladelet & $\mathrm{D}$ & 0 & 1,31 & 0,51 & 0,19 & Yes & 0,14 \\
\hline OC 15 & K5d & 2 & GH la1-1b1 & Epi-Pal / Neo / Chalco & ND & Bladelet & $\mathrm{P}$ & 0 & 2,02 & 0,76 & 0,19 & Yes & 0,32 \\
\hline OC 26 & - & 3 & $G \mathrm{H}$-11-1h1 & Epi-Pal / Neo / Chalco & EGD & Flake & w & - & 0,38 & 0,57 & 0,1 & No & 0,02 \\
\hline OC 27 & $16 \mathrm{c}$ & 3 & GH la1-1b1 & Epi-Pal / Neo / Chalco & $\mathrm{ND}$ & Bladelet core & W & 0 & 1,71 & 1,15 & 0,82 & No & 1,69 \\
\hline OC 31 & $\mathrm{H} 9 \mathrm{~b}$ & 4 & $\mathrm{H}$ la1-la2-Ib1-II & Epi-Pal / Neo / Chalco & NO & Bladelet & $\mathrm{D}$ & S & 0,97 & 0,82 & 0,22 & No & 0,16 \\
\hline OC 38 & $\mathrm{H} 9 \mathrm{~b}$ & 5 & GH la1-Ia2-Ib1-II & Epi-Pal / Neo / Chalco & $\mathrm{N}$ & Flake & D & 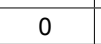 & 0,41 & 0,36 & 0,03 & No & 0,01 \\
\hline OC 39 & $\mathrm{H} 9 \mathrm{~b}$ & 5 & GH la1-Ia2-Ib1-II & Epi-Pal / Neo / Chalco & EGD & Flake & $\mathrm{w}$ & 0 & 0,72 & 0,39 & 0,06 & No & 0,02 \\
\hline OC 40 & $\mathrm{H} 9 \mathrm{~b}$ & 5 & |a1-la2-Ib1-II & Epi-Pal / Neo / Chalco & ND & Flake & W & 0 & 1,53 & 0,78 & 0,17 & No & 0,16 \\
\hline OC 54 & $19 a$ & 5 & GH la1-Ia2-Ib1-II & Epi-Pal / Neo / Chalco & $\mathrm{ND}$ & Flake & W & 0 & 0,6 & 0,31 & 0,1 & No & 0,02 \\
\hline OC 55 & $19 a$ & 5 & GH la1-Ia2-Ib1-II & Epi-Pal / Neo / Chalco & $\mathrm{ND}$ & Distal bladelet & $\mathrm{D}$ & 0 & 0,56 & 0,26 & 0,03 & No & 0,02 \\
\hline OC 35 & $17 \mathrm{c}$ & 4 & GH la2 & late Epi-Pal & $\mathrm{ND}$ & Flake & $\mathrm{W}$ & 0 & 0,61 & 0,52 & 0,09 & No & 0,02 \\
\hline OC 36 & $18 a$ & 4 & GH la2 & late Epi-Pal & EGD & Bladelet & $P$ & $P$ & 0,69 & 1,02 & 0,19 & Yes & 0,14 \\
\hline OC 37 & $18 \mathrm{c}$ & 4 & GHIa2 & late Epi-Pal & EGD & Flake / bladelet & D & 0 & 0,12 & 0,34 & 0,02 & No & 0,01 \\
\hline OC 57 & $18 \mathrm{~d}$ & 22 & GH VIII & early Epi-Pal & $\mathrm{ND}$ & Rejuv off bladelet core & W & 0 & 1,25 & 0,9 & 0,27 & Yes & 0,28 \\
\hline
\end{tabular}


in the 'Near East', a piece described variously as a "small flake" or "blade", coming from "the top of the Aurignacian IV level". ${ }^{23}$ The same study also included a blade from the nearby Karain Cave that came "from the travertine below the Aurignacian IV level". ${ }^{24}$ Using Optical Emission Spectroscopy these two pieces of obsidian were sourced to the southern Cappadocian region of Çiftlik (the analysts' 'Group 2b'), a series of outcrops now generally equated with the East Göllü Dağ source group. ${ }^{25}$ There is no other characterisation data from this region with which to contextualize our project.

\section{DATE OF THE ARCHAEOLOGICAL CONTEXT}

The date of the artefacts also needs to be considered, as certain sources have distinct histories of use. For example, during the Epi-Palaeolithic we only have evidence for the exploitation of East Göllü Dağ by central Anatolian and Levantine populations, and Bingöl and/or Nemrut Dağ by those living in south-eastern Anatolia. ${ }^{26}$ Over time we witness an increased number of sources coming into play. The Aceramic / PrePottery Neolithic sees the first use of Nenezi Dağ products, ${ }^{27}$ while the exchange of obsidian during the Pottery Neolithic and Chalcolithic is notable for its "more cosmopolitan and widespread" nature, ${ }^{28}$ with a range of northern Cappadocian (various Acıgöl types), Lake Van and north-eastern sources being exploited ${ }^{29}$ and the reconfiguration of long-standing exchange networks. ${ }^{30}$

\section{OTHER LINES OF EVIDENCE FOR LONG-DISTANCE INTERACTION}

Given the tiny quantities of obsidian recovered from the Öküzini Cave, it seems most likely that this exotic raw material was procured either through interaction with others in a form of exchange, or was collected in the process of undertaking more socio-economically significant activities, i.e. a form of 'embedded procurement'. ${ }^{31}$ It would thus be beneficial to have a clearer idea as to the geographic extent and orientation of these

23. Renfrew et al., 1966: 42-43, 65 and 71.

24. Ibid.: 43, 65 and 71.

25. Chataigner, 1998 : 285-292; Poidevin, 1998: 115-121.

26. Cauvin et Chataigner, 1998: 328-331.

27. Chataigner, $1998: 285-287$.

28. Renfrew et al., 1966: 48.

29. Cf. Bressy et al., 2005; Chataigner, 1998: 280-285.

30. Carter, Dubernet, King et al., 2008.

31. Cf. Binford, 1979. people's 'territory' during the Epi-Palaeolithic as a means of elucidating which possible sources they were visiting and / or the potential intermediaries through which they gained access to their obsidian. For the Neolithic and Chalcolithic periods we would similarly like to examine other forms of evidence to reconstruct the exchange routes through which obsidian may have been disseminated.

During the Epi-Palaeolithic most of the basic food and raw material requirements seem to have been procured within a territory of $20 \mathrm{~km}$ radius. From further afield, there are quantities of marine shell such as Dentalium and Columbella rustica that would have been procured from the Mediterranean ca $30 \mathrm{~km}$ to the south-east, ${ }^{32}$ while each of the Geological Horizons with obsidian also contained a few large flint blades that appear to have been procured ready-made from non-local sources (unfortunately, albeit from sites / sources currently unknown. ${ }^{33}$ Arguably it is the cave's iconography that provides us with the best evidence for community interaction over distance, with the abstract and figurative symbolism forming part of a shared repertoire with those living both in the Levant and Western Europe. ${ }^{34}$

Having taken the above factors into consideration, it was decided that a relatively wide range of archaeologically significant source materials should be included in the study, both Aegean and central Anatolian, the most archaeologically significant of which are East Göllü Dağ (as represented by products of the Kömürcü, East-Kayırlı and Sırça Deresi flows ${ }^{35}$ and Nenezi Dağ in southern Cappadocia, plus Dhemenegaki and Sta Nychia on Melos (fig. 1). We also considered geological samples from Giali (Dodecanese), Foça (west Anatolian coast), plus various outcrops of the Acıgöl massif in northern Cappadocia, specifically the 'East Acıgöl ante-caldera' geo-chemical compositional group (Kartaltepe, Tulucetepe and Boğazköy flows), the 'East Acıgöl post-caldera' type (Kocadağ), plus 'West Acıgöl' (Körüdağ, Acıgöl crater and Güneydağ flows) ${ }^{36}$ This is not to suggest that we ruled out the possibility of other Eastern Mediterranean sources (particularly given the above reference to the wider range being exploited in the Chalcolithic), but merely that one can construct an initial frame of reference through a detailed geo-temporal consideration of the material under consideration.

As detailed below, these source materials were characterised using the same technique as that employed to analyse the

32. Yalçınkaya, Otte et Kösem, 2002.

33. Léotard et López Bayón, 2002.

34. Marshack, 2002.

35. Poidevin, 1998 : 119-121.

36. Ibid. : 113-114. 
Öküzini Cave artefacts; full details of these analyses are published elsewhere. ${ }^{37}$

\section{THE ELEMENTAL CHARACTERISATION OF THE ÖKÜZINI CAVE OBSIDIAN}

All 56 artefacts were analysed using particle induced $\mathrm{X}$-ray emission [PIXE]. This technique is strictly non-destructive, relatively fast, involves minimal sample preparation and provides high-quality trace elemental data. ${ }^{38}$ Moreover, PIXE has already been employed successfully by our research group as a means of elementally discriminating the major obsidian sources of archaeological significance in Anatolia..$^{39}$ The analyses and subsequent data manipulation were undertaken by Le Bourdonnec and Poupeau, the study developing out of three of the present authors' collaborative analyses of obsidian from Çatalhöyük. ${ }^{40}$

Fifty-three of the artefacts were analysed by the vacuum microbeam line of the AIFIRA facility at the Centre d'Études Nucléaires de Bordeaux-Gradignan $[\mathrm{CENBG}],{ }^{41}$ the other three through the extracted beam of the AGLAE analytical system at the Laboratoire du Centre de Recherche et de Restauration des Musées de France [C2RMF]. ${ }^{42}$ In both cases the samples were excited by a proton beam of nominal energy $3 \mathrm{MeV}$, their induced $\mathrm{X}$-ray emission recorded by two $\mathrm{Si}(\mathrm{Li})$ detectors that allow the simultaneous detection of light and heavy elements, with 15 elemental contents recorded in total $(\mathrm{Na}, \mathrm{Al}, \mathrm{Si}, \mathrm{K}$, $\mathrm{Ca}, \mathrm{Ti}, \mathrm{Mn}, \mathrm{Fe}$ and $\mathrm{Zn}, \mathrm{Ga}, \mathrm{Rb}, \mathrm{Sr}, \mathrm{Y}, \mathrm{Zr}, \mathrm{Nb}$ respectively). ${ }^{43}$ Data treatments were performed using the 2000 version of the GUPIX software. ${ }^{44}$ It has been demonstrated elsewhere that the data obtained by the two PIXE instrumental facilities at AIFIRA and AGLAE are equivalent. ${ }^{45}$

37. Poupeau et al., 2010.

38 . The use of non-destructive techniques for obsidian characterisation studies in the larger region is becoming more commonplace for a variety of reasons pertaining to issues of laboratory facilities and cultural sensitivity, see Briois et al., 1997; Carter and Shackley, 2007; Gratuze, 1999; Khalidi et al., 2009; Poupeau et al., 2010, inter alia.

39. Le Bourdonnec et al., 2005; Lugliè et al., 2007 and 2008; Poupeau et al., 1998, 2005 and 2010, inter alia.

40. Carter et al., 2005 and 2006; Carter, Dubernet, King et al., 2008; Poupeau et al., 2005 and 2010.

41. A facility jointly run by the CNRS and Université Bordeaux 1 .

42. A CNRS-Ministère de la Culture facility based in Paris (Calligaro et al., 1996 and 2002)

43. Le Bourdonnec et al., 2005; Lugliè et al., 2007.

44. Campbell et al., 2000; Maxwell et al., 1989.

45. Le Bourdonnec et al., 2005; Poupeau et al., 2010.
Two compositional groups were identified amongst the 56 artefacts analysed, characterized by a "low" and a "high" content of major elements $\mathrm{Ca}, \mathrm{Fe}$ and trace elements $\mathrm{Sr}$, Zr. These groups also differ with regard to their contents in $\mathrm{Al}, \mathrm{Si}$, Ti, and $\mathrm{Zn}$ (table 4). Four artefacts, ÖC 23 and ÖC 28 in the low-Ca group, ÖC 19 and ÖC 48 in the high Ca group, exhibit anomalously low $\mathrm{Na}$ and correspondingly high $\mathrm{K}$ contents. Such behaviour, accompanied for the three of them with the lowest $\mathrm{Na}$ content, by a small depression in their $\mathrm{Si}$ content, was shown to result from post-depositional surface alteration. ${ }^{46} \mathrm{It}$ may not be coincidental that three of these artefacts came from the uppermost stratum GH 0 , whereby the different elemental contents might be viewed as the result of greater exposure to air and water, while ÖC 48 came from the pit from GH Ib1, whose fill would likely have been looser than surrounding deposits facilitating water percolation. That said, there was a number of other artefacts from the same strata that displayed no such distinctions in their $\mathrm{Na}$ and $\mathrm{K}$ composition, indicating that a number of variables are likely to be of influence in these matters, not just exposure to water/air, but also soil conditions, geometry and size of artefact, plus other environmental / contextual specificities (table 3 ).

Assigning the low- and high-Ca groups a specific volcanic source was achieved diagrammatically, by comparing the elemental compositions of the artefacts with those from the various Anatolian and Aegean source samples discussed above. According a geological source to these two groups was achieved through a principal component analysis (fig. 7) which demonstrates that our two compositional groups are compatible with the southern Cappadocian sources of East Göllü Dağ and Nenezi Dağ. Eastern Mediterranean obsidians and Eastern Anatolian peralkaline obsidians, whose elemental compositions are clearly different of those of the Öküzini artefacts, ${ }^{47}$ were not included in figure 7.

One final methodological point, we would argue that PIXE represents the best possible technique to use in this situation given that most of the Öküzini Cave artefacts are extremely small (fig. 6), with almost three-quarters of them being $<1 \mathrm{~cm}$ in length/width $(n=41)$. INAA and ICP techniques would not have been suitable as the entire assemblage had to be analysed non-destructively, while EDXRF would potentially have run into analytical problems due to the artefacts' thinness and small diameter. ${ }^{48}$ In contrast, with PIXE the beam usually penetrates no further than $50 \mu \mathrm{m}$ (microns), with the gamma-ray

46. Poupeau et al., 2010.

47. Cf. Shelford et al., 1982; Carter and Kilikoglou, 2007; Poidevin, 1998. 48. Cf. Davis et al., 1998. 
Table 4 - Element contents for the 56 obsidian artefacts from the Öküzini Cave and their source attribution $(N N Z D=$ Nenezi Dă̆, EGD = East Göllü Dă̆ $)$.

\begin{tabular}{|c|c|c|c|c|c|c|c|c|c|c|c|c|c|c|c|c|c|}
\hline Sample & Lab. ${ }^{*}$ & $\mathrm{Na}_{2} \mathrm{O}$ & $\mathrm{Al}_{2} \mathrm{O}_{3}$ & $\mathrm{SiO}_{2}$ & $\mathrm{~K}_{2} \mathrm{O}$ & $\mathrm{CaO}$ & $\mathrm{TiO}_{2}$ & MnO & $\mathrm{Fe}_{2} \mathrm{O}_{3}$ & $\mathrm{Zn}$ & $\mathbf{G a}$ & $\mathbf{R b}$ & $\mathrm{Sr}$ & $\mathbf{Y}$ & $\mathrm{Zr}$ & $\mathrm{Nb}$ & Type \\
\hline ÖC 001 & 1 & 3,7 & 12,7 & 77,4 & 4,5 & 0,46 & 0,064 & 0,070 & 0,88 & - & 17 & 227 & 19 & 23 & 89 & 26 & EGD \\
\hline ÖC 002 & 1 & 3,7 & 12,8 & 77,2 & 4,5 & 0,49 & 0,063 & 0,077 & 0,93 & 24 & 22 & 257 & 21 & 27 & 93 & 56 & EGD \\
\hline ÖC 003 & 1 & 3,6 & 12,8 & 78,0 & 4,4 & 0,40 & 0,062 & 0,064 & 0,76 & 19 & 15 & 210 & 15 & 22 & 71 & 47 & EGD \\
\hline ÖC 004 & 1 & 3,5 & 12,6 & 77,6 & 4,5 & 0,56 & 0,058 & 0,062 & 0,84 & - & 19 & 250 & 22 & - & - & 34 & EGD \\
\hline ÖC 010 & 1 & 3,1 & 12,8 & 78,3 & 4,5 & 0,48 & 0,062 & 0,054 & 0,66 & 19 & 11 & 169 & 7 & - & 71 & 21 & EGD \\
\hline ÖC 014 & 1 & 3,0 & 12,8 & 78,1 & 4,6 & 0,46 & 0,058 & 0,064 & 0,77 & 22 & 16 & 153 & 10 & 30 & 77 & 13 & EGD \\
\hline ÖC 017 & 1 & 3,6 & 13,0 & 77,7 & 4,4 & 0,42 & 0,057 & 0,070 & 0,85 & 23 & 23 & 250 & 27 & - & 97 & 65 & EGD \\
\hline ÖC 018 & 1 & 3,2 & 12,7 & 78,1 & 4,6 & 0,48 & 0,072 & 0,064 & 0,80 & 20 & 15 & 216 & 19 & - & 73 & 29 & EGD \\
\hline ÖC 023 & 1 & 1,9 & 12,6 & 76,4 & 7,1 & 0,48 & 0,063 & 0,059 & 0,78 & 27 & 14 & 270 & 13 & - & 85 & 32 & EGD \\
\hline ÖC 025 & 1 & 3,4 & 13,3 & 77,0 & 4,4 & 0,61 & 0,073 & 0,077 & 0,90 & 32 & 20 & 217 & 10 & - & 97 & 24 & EGD \\
\hline ÖC 026 & 1 & 3,1 & 13,0 & 77,3 & 5,0 & 0,52 & 0,063 & 0,068 & 0,87 & 27 & 15 & 287 & 24 & - & 77 & - & EGD \\
\hline ÖC 028 & 1 & 2,8 & 12,4 & 77,4 & 5,3 & 0,47 & 0,059 & 0,071 & 0,89 & - & 18 & 218 & 15 & - & 87 & 38 & EGD \\
\hline ÖC 030 & 1 & 3,3 & 12,7 & 78,5 & 4,6 & 0,50 & 0,061 & 0,057 & 0,74 & 31 & 17 & 242 & 10 & - & 76 & 19 & EGD \\
\hline ÖC 036 & 1 & 3,2 & 12,7 & 77,9 & 5,0 & 0,45 & 0,076 & 0,064 & 0,89 & 26 & 18 & 234 & 22 & 30 & 73 & - & EGD \\
\hline ÖC 037 & 1 & 3,1 & 12,8 & 78,4 & 4,5 & 0,47 & 0,056 & 0,051 & 0,63 & 22 & 10 & 189 & 16 & 35 & 58 & 26 & EGD \\
\hline ÖC 039 & 1 & 3,6 & 12,6 & 78,1 & 4,4 & 0,42 & 0,054 & 0,077 & 0,89 & 24 & 15 & 230 & 17 & 49 & 69 & 47 & EGD \\
\hline ÖC 044 & 1 & 3,5 & 12,8 & 78,2 & 4,4 & 0,49 & 0,051 & 0,053 & 0,70 & 22 & 11 & 174 & 11 & - & 68 & 31 & EGD \\
\hline ÖC 046 & 1 & 3,7 & 12,7 & 78,2 & 4,3 & 0,39 & 0,062 & 0,053 & 0,67 & 19 & 15 & 165 & 16 & - & 64 & 32 & EGD \\
\hline ÖC 047 & 1 & 3,3 & 12,7 & 78,5 & 4,5 & 0,44 & 0,051 & 0,055 & 0,66 & 24 & 14 & 183 & 16 & - & 70 & 26 & EGD \\
\hline ÖC 051 & 1 & 3,3 & 12,6 & 78,5 & 4,5 & 0,45 & 0,055 & 0,056 & 0,64 & 17 & 14 & 186 & 14 & 22 & 78 & 21 & EGD \\
\hline ÖC 052 & 1 & 3,5 & 12,6 & 78,1 & 4,4 & 0,47 & 0,058 & 0,072 & 0,84 & 25 & 17 & 224 & 6 & 23 & 85 & 35 & EGD \\
\hline ÖC 053 & 1 & 3,7 & 12,7 & 77,4 & 4,3 & 0,57 & 0,075 & 0,076 & 0,97 & - & 16 & 223 & 10 & 30 & 83 & 36 & EGD \\
\hline ÖC 056 & 1 & 3,6 & 12,7 & 78,2 & 4,3 & 0,46 & 0,054 & 0,058 & 0,67 & 18 & 14 & 176 & 12 & 24 & 60 & 15 & EGD \\
\hline ÖC 005 & 1 & 3,8 & 13,9 & 74,9 & 4,2 & 1,20 & 0,121 & 0,077 & 1,26 & 57 & 19 & 185 & 161 & 23 & 177 & 34 & NNZD \\
\hline ÖC 006 & 1 & 3,8 & 13,7 & 75,4 & 4,3 & 0,95 & 0,128 & 0,069 & 1,17 & 49 & 12 & 189 & 166 & - & 172 & - & NNZD \\
\hline ÖC 007 & 1 & 3,9 & 13,7 & 75,5 & 4,2 & 1,00 & 0,105 & 0,066 & 1,10 & 39 & 16 & 163 & 141 & - & 139 & 22 & NNZD \\
\hline ÖC 008 & 2 & 3,8 & 13,7 & 75,3 & 4,1 & 1,10 & 0,120 & 0,070 & 1,23 & 47 & 18 & 175 & 139 & 22 & 116 & 17 & NNZD \\
\hline ÖC 009 & 1 & 3,7 & 14,0 & 75,3 & 4,1 & 1,11 & 0,102 & 0,062 & 1,07 & 38 & 14 & 162 & 108 & - & 122 & 27 & NNZD \\
\hline ÖC 011 & 1 & 3,7 & 13,8 & 75,5 & 4,3 & 1,10 & 0,114 & 0,063 & 1,04 & 32 & 12 & 168 & 104 & - & 127 & 26 & NNZD \\
\hline ÖC 012 & 1 & 4,1 & 13,8 & 75,1 & 4,2 & 1,02 & 0,121 & 0,079 & 1,28 & 47 & 22 & 183 & 116 & 31 & 144 & 31 & NNZD \\
\hline ÖC 013 & 1 & 3,8 & 13,8 & 75,5 & 4,1 & 1,24 & 0,108 & 0,052 & 0,94 & 40 & 16 & 146 & 95 & - & 133 & 20 & NNZD \\
\hline ÖC 015 & 1 & 3,4 & 13,7 & 76,3 & 4,3 & 0,92 & 0,116 & 0,053 & 0,97 & 38 & 14 & 153 & 95 & 15 & 110 & 14 & NNZD \\
\hline ÖC 016 & 1 & 3,8 & 13,8 & 75,1 & 4,3 & 1,01 & 0,117 & 0,082 & 1,36 & 44 & 19 & 219 & 152 & - & 183 & 44 & NNZD \\
\hline ÖC 019 & 1 & 1,3 & 13,6 & 73,1 & 8,2 & 1,17 & 0,128 & 0,069 & 1,18 & 49 & 17 & 254 & 139 & - & 199 & 40 & NNZD \\
\hline ÖC 020 & 1 & 4,0 & 13,7 & 75,3 & 4,3 & 0,96 & 0,112 & 0,070 & 1,22 & 44 & 16 & 217 & 132 & - & 175 & 39 & NNZD \\
\hline ÖC 021 & 1 & 3,9 & 13,7 & 75,5 & 4,2 & 0,98 & 0,123 & 0,066 & 1,14 & 44 & 14 & 173 & 130 & - & 142 & 37 & NNZD \\
\hline ÖC 022 & 1 & 3,9 & 13,8 & 74,9 & 4,2 & 1,09 & 0,127 & 0,083 & 1,41 & 52 & 22 & 224 & 165 & - & 149 & 52 & NNZD \\
\hline ÖC 024 & 1 & 3,9 & 14,1 & 74,8 & 4,2 & 0,99 & 0,128 & 0,080 & 1,34 & 44 & 18 & 186 & 136 & - & 168 & 45 & NNZD \\
\hline ÖC 027 & 2 & 4,0 & 13,8 & 75,2 & 4,1 & 1,03 & 0,127 & 0,063 & 1,08 & 36 & 13 & 143 & 117 & 14 & 115 & 15 & NNZD \\
\hline ÖC 029 & 1 & 3,7 & 13,6 & 73,9 & 4,5 & 1,22 & 0,153 & 0,085 & 1,52 & 51 & 23 & 209 & 131 & 31 & 150 & 18 & NNZD \\
\hline ÖC 031 & 1 & 3,6 & 13,6 & 75,0 & 4,3 & 1,00 & 0,131 & 0,070 & 1,31 & 49 & 15 & 204 & 147 & - & 135 & 31 & NNZD \\
\hline ÖC 032 & 1 & 3,8 & 13,8 & 74,9 & 4,2 & 1,25 & 0,136 & 0,079 & 1,31 & 44 & 15 & 192 & 117 & 47 & 179 & 24 & NNZD \\
\hline ÖC 033 & 1 & 3,8 & 13,9 & 74,8 & 4,1 & 1,33 & 0,139 & 0,076 & 1,21 & 44 & 13 & 196 & 130 & 48 & 120 & - & NNZD \\
\hline ÖC 034 & 1 & 3,9 & 13,9 & 75,0 & 4,2 & 1,16 & 0,107 & 0,071 & 1,20 & 43 & 16 & 211 & 120 & - & 156 & 31 & NNZD \\
\hline ÖC 035 & 1 & 3,5 & 13,7 & 75,6 & 4,3 & 1,05 & 0,122 & 0,072 & 1,14 & 38 & 17 & 174 & 118 & - & 194 & 21 & NNZD \\
\hline ÖC 038 & 1 & 4,1 & 13,8 & 75,0 & 4,2 & 1,04 & 0,116 & 0,082 & 1,33 & 46 & 20 & 198 & 180 & 37 & 143 & 28 & NNZD \\
\hline ÖC 040 & 1 & 3,6 & 13,7 & 75,6 & 4,2 & 0,97 & 0,118 & 0,073 & 1,28 & 45 & 19 & 191 & 151 & - & 157 & 36 & NNZD \\
\hline ÖC 041 & 1 & 3,7 & 14,2 & 74,7 & 4,1 & 1,29 & 0,133 & 0,064 & 1,17 & 38 & 18 & 148 & 145 & 27 & 126 & 45 & NNZD \\
\hline ÖC 042 & 2 & 3,6 & 14,0 & 74,7 & 4,2 & 1,23 & 0,144 & 0,070 & 1,30 & 54 & 18 & 157 & 140 & 15 & 130 & 13 & NNZD \\
\hline ÖC 043 & 1 & 3,8 & 13,9 & 75,3 & 4,1 & 1,15 & 0,130 & 0,062 & 1,11 & 38 & 17 & 172 & 148 & 34 & 138 & - & NNZD \\
\hline ÖC 045 & 1 & 3,9 & 13,7 & 75,8 & 4,1 & 0,99 & 0,096 & 0,065 & 1,09 & 37 & 14 & 160 & 126 & - & 101 & 31 & NNZD \\
\hline ÖC 048 & 1 & 1,8 & 13,6 & 74,4 & 6,9 & 1,14 & 0,121 & 0,065 & 1,04 & 40 & 15 & 188 & 134 & - & 146 & 34 & NNZD \\
\hline ÖC 050 & 1 & 4,0 & 13,7 & 75,7 & 4,1 & 1,01 & 0,117 & 0,061 & 1,06 & 40 & 15 & 170 & 126 & 21 & 120 & - & NNZD \\
\hline ÖC 054 & 1 & 4,0 & 13,6 & 75,4 & 4,2 & 0,98 & 0,119 & 0,069 & 1,19 & 47 & 18 & 170 & 165 & 28 & 147 & 23 & NNZD \\
\hline ÖC 055 & 1 & 3,9 & 13,8 & 76,0 & 4,1 & 0,88 & 0,103 & 0,056 & 0,93 & 34 & 15 & 141 & 118 & 19 & 100 & 26 & NNZD \\
\hline ÖC 057 & 1 & 4,0 & 13,8 & 75,4 & 4,1 & 1,00 & 0,118 & 0,066 & 1,14 & 60 & 18 & 171 & 137 & - & 114 & 33 & NNZD \\
\hline
\end{tabular}




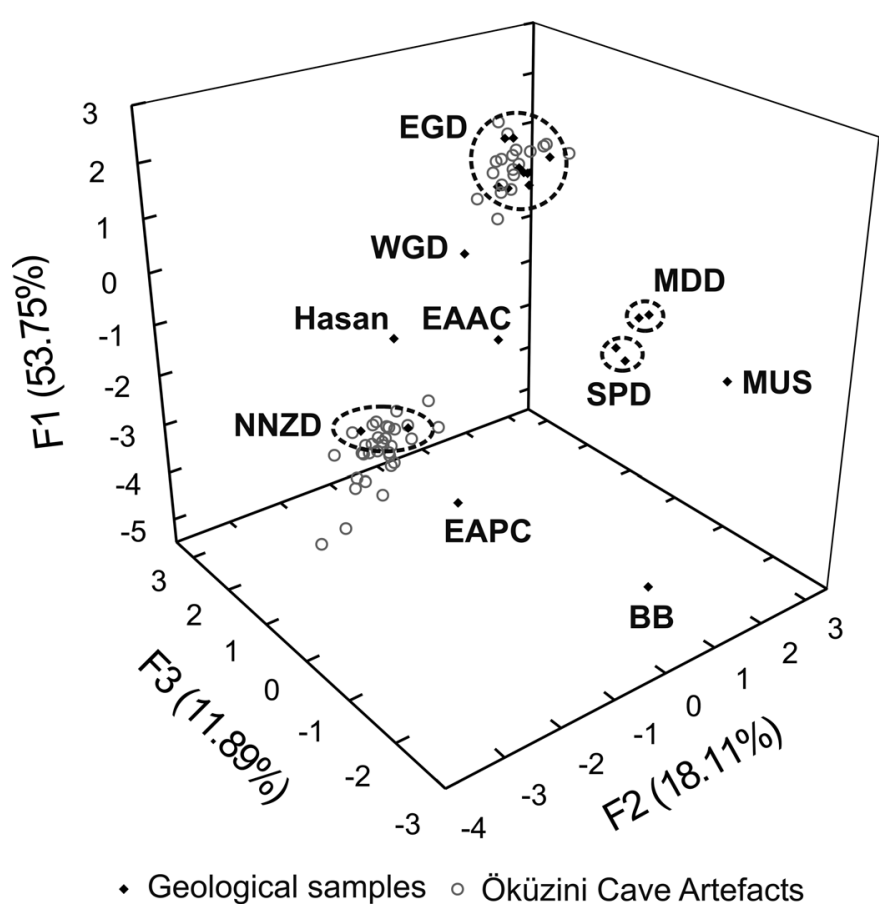

Fig. 7 - A principal component analysis of the trace elemental data from the PIXE analysis of the 56 Öküzini Cave obsidian artefacts and major Aegean and Anatolian sources (F.-X. Le Bourdonnec).

and X-ray emission mainly taking place within $10-20 \mu \mathrm{m}$, whereby the thinness of the Öküzini Cave artefacts had no undue effect on the analytical process and results. ${ }^{49}$

\section{RESULTS}

The results of the obsidian analyses are presented here by geo-chronological horizon starting with the earliest finds, their full contextual details presented in table 3 . The sourcing data is accompanied by discussion of not only the artefacts technotypological specifics, but also a more general overview of the archaeology of that period in the cave and its climatic and broader Anatolian / Near Eastern context, the latter derived from the chrono-cultural system of the Maison de l'Orient. ${ }^{50}$

Regarding absolute dates, there is a number of radiocarbon determinations from the Geological Horizons containing obsidian, though they are not without issue. A critical evaluation of the entire sequence of dates (considering lab, method,

49. Summerhayes et al., 1998: 134-135.

50. Aurenche et al., 2001; Hours et al., 1994. sample type and context), led the excavators to view those generated from bone to be highly problematic, ${ }^{51}$ with López Bayón et al. arguing that those produced by the Oxford accelerator from carbon should be used as the basis for the absolute chronology of the Öküzini Cave sequence. ${ }^{52}$ In this section we follow their lead, while at the same time reproducing all radiocarbon dates from the pertinent strata in table 2 (the majority of which were derived from charcoal).

\section{GH VIII - EARLY EPI-PALAEOLITHIC (WARM PHASE) / PERIOD 0}

Described as the Öküzini Cave's richest archaeological stratum, GH VIII forms part of the early Epi-Palaeolithic occupation sequence, dated to the late $17^{\text {th }}$ - first half of the $16^{\text {th }}$ millennia cal. BC (tables 1-2). This horizon is equated with the excavators' cultural Phase II, and climatically is located within the Warm Phase, ${ }^{53}$ during which time the cave's occupants overwhelmingly favoured the hunting of ovicaprines, primarily wild goat (fig. $3-4){ }^{54}$

GH VIII contained evidence for a significant level of stone tool production, with various radiolarites used to make both blades and bladelets flaked by percussion techniques, primarily from unipolar cores. Various microlith types are documented, with retouched bladelets, micropoints, microgravettes, lunates, trapezes and isoscele triangles, while other tool forms include endscrapers on blades. ${ }^{55}$ Amongst this rich chipped stone assemblage was a single piece of obsidian ÖC 57, that appears to be a small rejuvenation flake struck from the face of a bladelet core made of Nenezi Dağ obsidian (fig. 5: a).

If we can be certain that ÖC 57 belongs to this stratum, it would represent the earliest evidence for the long-distance movement of Cappadocian obsidian. To substantiate such a claim we need to critically consider the artefact's archaeological integrity. The first question that needs to be asked, is why should there be such a major chronological gap between this piece and the next obsidian finds in GH Ia2, a hiatus of perhaps as long as 7000 years. Might it make more sense to argue that ÖC 57 is in fact intrusive, having fallen out of a more recent stratum higher-up the stratigraphic profile? The hypothesis seems tempting given that the piece came from a square that

51. Goldberg and Bar-Yosef, 2002: 42; López Bayón et al., 2002: 49-51.

52. López Bayón et al., 2002: 49-51, fig. 3-5.

53. Ibid.: 52-54, table 1, fig. 6a and 7b; López Bayón, Léotard et Kartal, 2002: 27-31; Otte et al., 2003: 329.

54. Otte et al., 2003: 333 .

55. Léotard et López Bayón, 2002 : 131, fig. 10-11; Kartal, 2002: 236. 


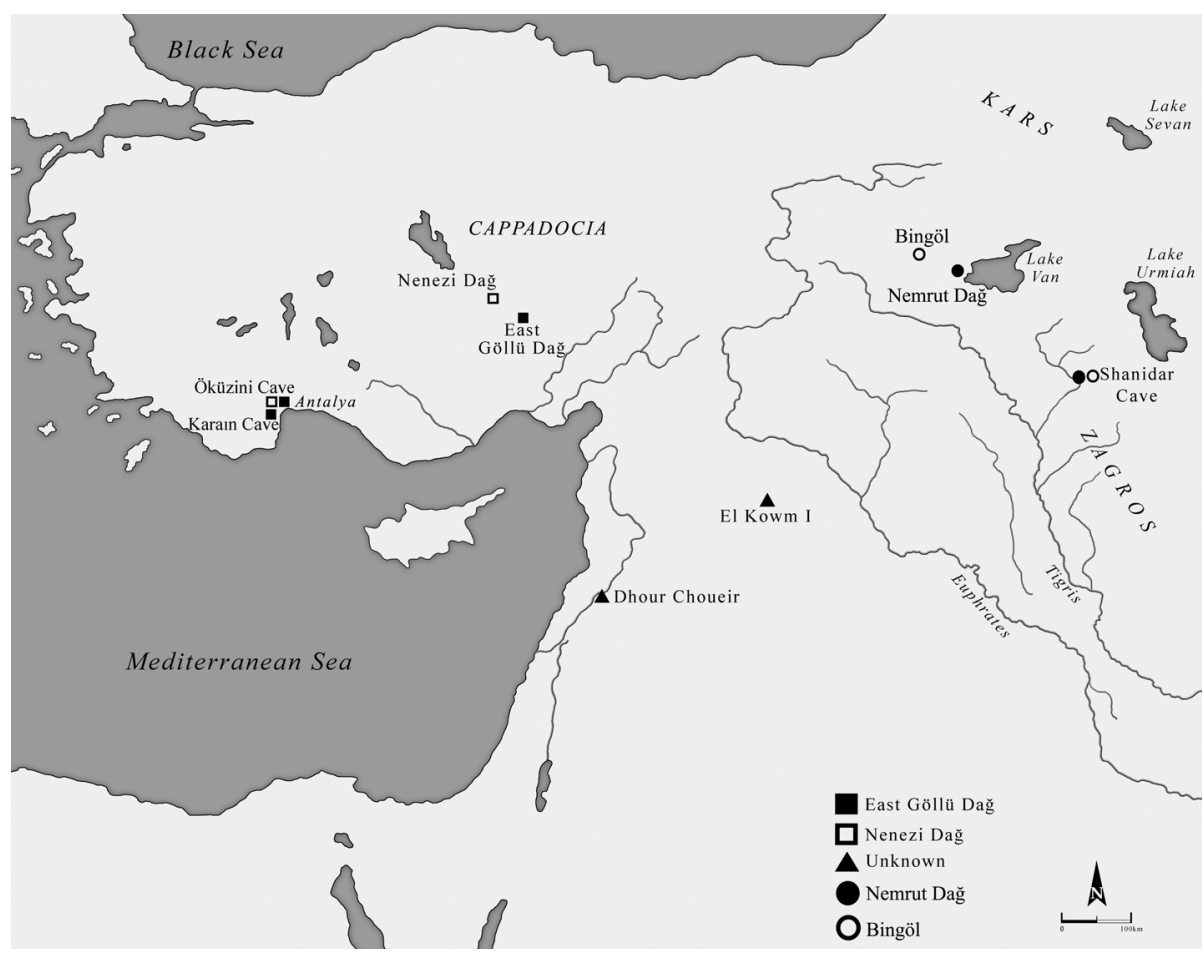

Fig. 8 - Distribution of Anatolian obsidian in Period 0 (Epi-Palaeolithic) and earlier Palaeolithic periods (M. Milić).

immediately abutted the East / Secondary profile (locus I8d/22 [fig. 4]). That said, the piece came from 'quadrant d' (the SW part of the square), which places it at least $50 \mathrm{~cm}$ away from the actual section (fig. 2) ${ }^{56}$ While one would have preferred ÖC 57 to have come from a square further away from the profile, it should be noted that there is no record of any intrusive ceramics or other diagnostic later material recovered from this context. Moreover, ÖC 57 came from the same trench and layer as one of the three Oxford lab radiocarbon samples (I8b/22 [table 2]), further suggesting its uncontaminated nature. ${ }^{57}$ Finally, one should not forget that this is not the first time obsidian has been recovered from a later Palaeolithic context at this site. An obsidian flake is reported from the top of the "Aurignacian IV level" from the 1950's excavation, while another came from "the travertine below the Aurignacian IV level" at neighbouring Karain B (fig. 8); both of these artefacts were subsequently

56. See Yalçınkaya et Otte, 2002: fig. 2.

57. It should be noted that there is some contradiction in the publication as to this context's Geological Horizon, as it is also listed as GH V in Yalçınkaya et al. (2002: table 7, 344), however the unit is described as belonging to GH VIII in Goldberg and Bar-Yosef (2002: 47, table 3), while GH VIII was also clearly written on the bag of chipped stone from which ÖC 57 was sampled (T. Carter, personal observation). shown to be made of obsidian from the Çiftlik source (East Göllü Dağ). ${ }^{58}$ More recently, Albrecht has reported a single cortical flake from one of the lowest Upper Palaeolithic levels at Karain B, from a stratum that appears to be broadly contemporary with GH VIII; ${ }^{59}$ this piece has yet to be sourced.

If ÖC 57 did indeed belong to GH VIII, then chronologically this places the find earlier than the Maison de l'Orient's Period 0 [15,500-14,200 cal. BP], broadly contemporary with the Epi-Palaeolithic cultures of the Geometric Kebaran in the Levant, and Zarzian further to the east. ${ }^{60}$ Hitherto, Period 0 represented the first phase during which we had evidence for the movement of Cappadocian obsidians beyond their source areas; ÖC 57 now represents one of the best documented pieces from conceivably an even earlier date. Furthermore, this artefact pushes back the earliest date for the long distance exploitation of Nenezi Dağ products by some 8000 years, with

58. Both pieces having come from the 1950's excavations by Prof. Kökten (Renfrew et al., 1966: 42-43).

59. The piece comes from Archaeological Horizon 29, from which a single radiocarbon determination produced on a bone gave a date of 14,200 \pm $500 \mathrm{BP}$, a determination that was considered possibly too young due to diagenesis (Albrecht, 1988: 213-214, fig. 2: 6).

60. Cauvin, 2000: 13-14; Hours et al., 1994. 
the material's first use previously dated to the $9^{\text {th }}$ millennium cal. BC at the early Pre-Pottery Neolithic B [PPNB] sites of Munhata in Israel and Shillourokambos on Cyprus (fig. 1) ${ }^{61}$ During Period 0 we are dealing with only tiny quantities of obsidian from a handful of sites over a relatively wide area. Aside from the Öküzini and Karain B material, there is a tiny quantity of obsidian from roughly contemporary sites of the Kebaran culture (14,000-12,000 BP) in the Levant. From the same broad period there are also two bladelets from El Kowm I (Syria) plus a bladelet from Dhour Choueir (Lebanon) unfortunately, this material has yet to be sourced (fig. 8) ${ }^{62}$

While ÖC 57 may indeed represent the earliest evidence we have for the distant use of Cappadocian obsidian (at source exploitation of Göllü Dag materials goes back to the Lower Palaeolithic), ${ }^{63}$ we should not forget that the SE Anatolian sources have an even earlier history of long-distance procurement, with two pieces of obsidian found in an Upper Palaeolithic stratum of the Shanidar Cave in northern Iraq (dated $c a 30,000 \mathrm{BP}$ ). One of these pieces when analysed was shown to be a peralkaline product of Bingöl and / or Nemrut Dağ, sources that lay some $300-400 \mathrm{~km}$ north-west of the site (fig. 8). ${ }^{64}$

As-the-crow-flies, the distance from the Öküzini Cave to Nenezi Dağ is approximately $380 \mathrm{~km}$; however, a more realistic circuitous route either around the southern edge of Konya Plain, or via Cilicia would be in the region of 400$600 \mathrm{~km} .{ }^{65}$ Given that the inhabitants of the cave are known to have exploited a relatively small ecological niche of no more than $30 \mathrm{~km}$ radius for their foodstuffs and lithic resources, ${ }^{66}$ it seems extremely unlikely that they would have procured the obsidian from Cappadocia themselves. Of course, the catchment area of the seasonal cave residence would have been significantly smaller than that exploited by these people during an annual / longer-term cycle of movement, though even this territory is unlikely to encompass the mountain of Nenezi Dağ which is some $400-600 \mathrm{~km}$ distant. ${ }^{67}$ When one takes all of these points into consideration, it seems most likely that the inhabitants of the Öküzini Cave gained access to the obsidian through intermediary populations. ${ }^{68}$ Unfortunately we have

61. Briois et al., 1997; Cauvin et Chataigner, 1998: 286-287, fig. 5: a-b.

62. Cauvin, 1991: 166; Cauvin et Chataigner, 1998: 328-329.

63. Slimak, 2004; Slimak et al., 2008.

64. Renfrew et al., 1966: 40-41.

65. Ibid. 1966: fig. 4b.

66. Atici and Stutz, 2002; Martinoli, 2004; Pawlikowski, 2002.

67. For example, roughly contemporary Epi-Palaeolithic foragers from the

Levantine coast were estimated to have had a territory of 'only' 250-350

km (Bar-Yosef and Belfer-Cohen, 1989).

68. One can further point out that the one season when the cave's inhabitants precious little idea as to who these peoples were, as the early Epi-Palaeolithic occupation of the area between Antalya and Cappadocia remains terra incognita. ${ }^{69}$

\section{GH IA1 AND IA2 - LATE EPI-PALAEOLITHIC (YOUNGER DRYAS) / PERIOD 1}

Geological Horizons Ia1 and Ia2 constitute Öküzini's uppermost late Epi-Palaeolithic deposits (with Ial overlaying Ia2), a re-occupation of the cave that represents the excavators' cultural Phase V, climatically relating to the Younger Dryas (table 1, fig. 3-4). ${ }^{70}$ In one area, these strata were cut by a Neolithic pit (GH Ib1), while GH Ia2 was disturbed by a series of Neolithic and Chalcolithic features (GH 03, 04 and 05);11 none of the obsidian from these strata came from these disturbed areas. The four radiocarbon determinations associated with GH Ia2, two of which were generated from the preferred charcoal samples, give dates of the early $12^{\text {th }}-$ mid $11^{\text {th }}$ millennia cal. BC (table 2), Period 1 in the Maison de l'Orient's chronological scheme. ${ }^{72}$

Radiolarites were once again the dominant raw material, employed to make blades from unipolar prismatic and pyramidal nuclei using a pressure-flaking technique. ${ }^{73}$ The tools of GH Ia2 include new types such as large blades with lateral retouch, scrapers on large flakes, and small flakes with multiple notches. The microlithic component included geometric forms such as trapezes, plus isosceles and scalene triangles, while the GH Ia1 material had microburins of the Krukowski type. ${ }^{74} \mathrm{GH}$ Ial also produced a series of long blades up to $8 \mathrm{~cm}$ long that were imported ready-made, together with truncated and splintered blades, notched blades and micro-scrapers. The three pieces of obsidian from these strata came from GH Ia2, comprising two bladelet segments of East Göllü Dağ obsidian (ÖC 36 [fig. 5b] and ÖC 37) and a tiny non-cortical flake sourced to Nenezi Dağ (ÖC 35).

The procurement of obsidian by the dwellers of the Öküzini Cave during GH Ia2 occurred at a time when we view the first major expansion in the long-distance circulation of Cappadocian products. Small quantities of central Anatolian

moved elsewhere is winter, i.e. the time when the quarries would have been snow covered and inaccessible.

69. Baird, 2005; Binder, 2002: 81.

70. López Bayón, Léotard et Kartal, 2002 : 32-33 and 37-38, fig. 4a.

71. Otte et al. 2003: 331.

72. Aurenche et al., 2001: 1194-1196; Cauvin, 2000: 34-50, 75-95.

73. Léotard et López Bayón, 2002 : 133-134, fig. 22-24.

74. Kartal, 2002: 236; Léotard et López Bayón, 2002: 133-134, fig. 22-24. 


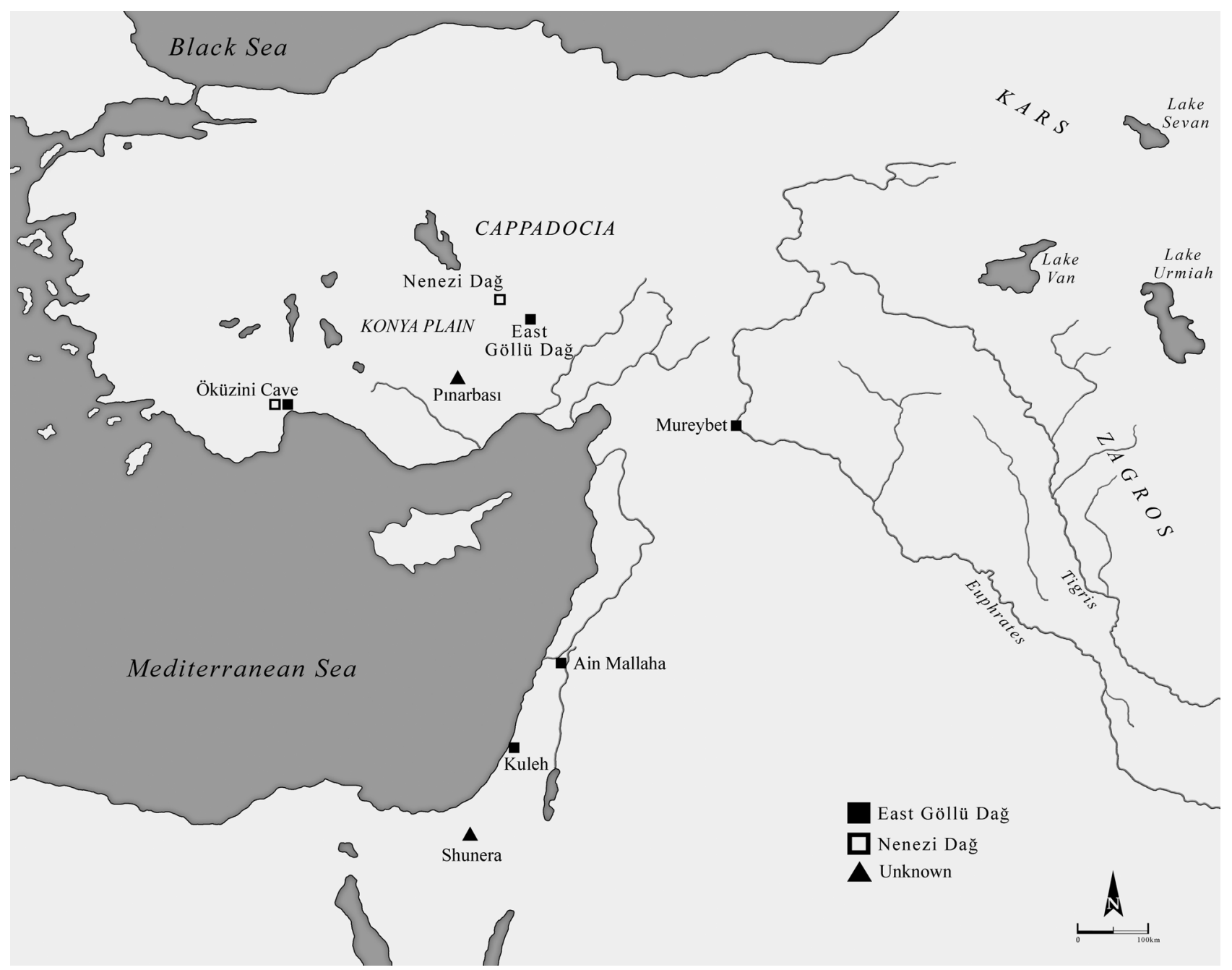

Fig. 9 - Distribution of Cappadocian obsidian in Period 1 (Late Epi-Palaeolithic) (M. Milić).

obsidian are now recorded from a number of Natufian sites throughout the Levant (fig. 9), including Mureybet, Abu Hureyra, Shunera, Ain Mallhala (Eynan) and Kuleh, communities that appear to have primarily procured the material in the form of ready-made blades and bladelets; where analysed, the material has all been sourced to East Göllü Dağ. ${ }^{75}$ While the two Öküzini Cave bladelets would seem to fit this pattern, the tiny Nenezi Dağ flake is an interesting anomaly given that-as noted above - the first evidence for this raw material being consumed at distance had until now been placed much later during the early/middle PPNB (Period $3 / 9^{\text {th }}-8^{\text {th }}$ millen-

75. Cauvin et Chataigner, 1998: 330-331; Delerue, 2007: 217; Delerue et Poupeau, 2007; Moore, 2000: 182. nia cal. BC [fig. 1]) ${ }^{76}$ This small but complete flake might further suggest the on-site working of Nenezi Dağ obsidian. Ultimately, given that the Öküzini Cave lies on the other side of Cappadocia to the Levant, it seems safe to assume that there were a number of different exchange networks in operation during the $12^{\text {th }}-11^{\text {th }}$ millennia cal. $\mathrm{BC}$, with differences in both which sources were being exploited and the form(s) in which their products circulated.

As to the identity of those responsible for providing the cave's inhabitants with obsidian during this time, recent survey in the Konya Plain has found a number of sites with a

76. Briois et al., 1997; Cauvin et Chataigner, 1998 : 332-337; Chataigner, 1998 : 286-287. 
'microlithic' component (not least Pinarbaşı and Boncuklu), some of which are potentially Epi-Palaeolithic contemporaries of GH Ia2 Öküzini (fig. 9). ${ }^{77}$ All of these sites assemblages were dominated by obsidian - presumably of Cappadocian origin-the material having potentially been directly procured by members of these small communities, the sources lying within the aforementioned 250-350 km range / territory of Levantine hunter-gatherers. Yet precious little of this obsidian seems to have trickled 'down-the-line' to the inhabitants of the Öküzini Cave or their neighbours, suggesting only limited interactions between the Epi-Palaeolithic populations of the Antalya region and the Konya Plain; ${ }^{78}$ this is an issue that we return to below.

\section{GH IB1- LATE NEOLITHIC (EARLY HOLOCENE) - PERIOD 6}

GH Ib1 comprises the fill of a Neolithic pit that had been cut into strata GH Ia1, Ia2 and II at the western end of the South / Main profile (fig. 2-3), part of the excavators' cultural Phase VI and relating climatically to the Early Holocene. ${ }^{79}$ Four of the five associated radiocarbon determinations (all charcoal) are problematic as they span the $9^{\text {th }}$ to the mid $8^{\text {th }}$ millennium cal. BC (table 2), which, given that the Ceramic Neolithic in Anatolia does not start until ca 7000 cal. BC, ${ }^{80}$ suggests that these samples were residual. The fifth determination of 6558-6994 cal. BC $(1 \sigma=49.2 \%)$ seems a much more likely date for this feature, i.e. Early-Late Pottery Neolithic in a central / southwestern Anatolian context. ${ }^{81}$

Unfortunately little detail is provided on the chipped stone from the cave's uppermost levels, with the contents of GH Ib1 discussed together with those from the above GH 0 of EarlyLate Chalcolithic date. The material is described as fragmentary, poor and primarily made of radiolarite; unipolar blade technologies dominate, with modified end-products including piercers, dihedral burins, and pièces esquillées, while others were glossed, conceivably from use as sickles. ${ }^{82}$ The microburin technique is again represented, as were irregular geometric microliths, though as with much of the pit's contents, they are thought to be residual Epi-Palaeolithic material. ${ }^{83}$

77. Baird, 2005, 2007a and 2008

78. Baird, 2007b: 293.

79. López Bayón, Léotard et Kartal, 2002: 32-33, 37, fig. 4a.

80. Which starts ca 7000 cal. BC (cf. Last, 2005: 127; Moore, 1995).

81. See papers in Gérard and Thissen, 2002.

82. Léotard et López Bayón, 2002: 134.

83. Kartal, 2002: 236.
Fourteen pieces of obsidian came from units associated exclusively with the contents of GH Ib1. In turn, we also discuss here a further nine artefacts that came from mixed deposits that may have partly formed a part of this pit, being labelled as 'GH Ia1-Ib1 mixture' and 'GH Ia1-Ia2-Ib1-II mixture' (tables 2-3). Of the aforementioned 14 pieces, half were sourced to East Göllü Dağ and half to Nenezi Dağ. While seven of these were in the form of undiagnostic tiny non-cortical flakes, there were also three bladelets of East Göllü Dağ obsidian (ÖC 30, ÖC 44 and ÖC 53 [fig. 5: d]) and two of Nenezi Dağ (ÖC 09, ÖC 45), pieces that we consider residual Epi-Palaeolithic material given their typo-technological characteristics. There are however two pieces that are much more likely to be genuine Neolithic products. The first is the medial section of a primary series blade (as attested by the remnant natural surface) from an opposed platform technology made of East Göllü Dağ obsidian (ÖC 46 [fig. 5: c]). The production of blades from opposed platform cores using this specific raw material is something that we almost exclusively associate with the Aceramic Neolithic in Central Anatolia $\left(9^{\text {th }}-8^{\text {th }}\right.$ millennia cal. BC), as attested at the quarry-based atelier of KaletepeKömürcü, ${ }^{84}$ at 'Aşıklı culture' sites of western Cappadocia ${ }^{85}$ and at Canhasan III and Çatalhöyük (Level Pre-XII) in the Konya Plain. ${ }^{86}$ Bipolar blade technologies are also known from Early and Late Neolithic contexts $\left(7^{\text {th }}\right.$ millennium cal. BC), as at Çatalhöyük for example, but at this site at least, such products are almost always made from Nenezi Dağ obsidian. ${ }^{87}$

The second piece from GH Ibl that should date to the Holocene is a small tanged point made on a prismatic blade of Nenezi Dağ obsidian modified with unifacial retouch (ÖC 42 [fig. 5: h]). While we struggle to find an exact parallel for this arrowhead, short projectiles such as these tend to be a diagnostic feature of Late Neolithic and Early Chalcolithic assemblages, as at Çatalhöyük in the Konya Plain (late $7^{\text {th }} /$ $6^{\text {th }}$ millennia cal. BC), ${ }^{88}$ though they can continue much later, as evidenced by a not dissimilar projectile from Middle Chalcolithic Yumuktepe/Mersin $\left(6^{\text {th }}-5^{\text {th }}\right.$ millennia cal. BC) ${ }^{89}$

Of the nine remaining pieces from mixed deposits (table 3), seven were sourced to Nenezi Dağ and two to East Göllü Dağ; just under half of this material can be categorised as tiny non-cortical flakes $(n=4)$. The other five pieces comprise an

84. Binder and Balkan-Atl1, 2001, inter alia.

85. Abbès et al., 1999; Balkan-Atl1, 1998; Kayacan, 2003.

86. Ataman, 1988: 70 and fig. 29.A and 34; Carter, Conolly and Spasojević, 2005: 472, fig. 11.5b-c.

87. T. Carter, personal observation.

88. Bialor, 1962: 97, fig. 10,6; Carter et al., 2006: fig. 162. 89. Garstang 1953: 106, fig. 66. 


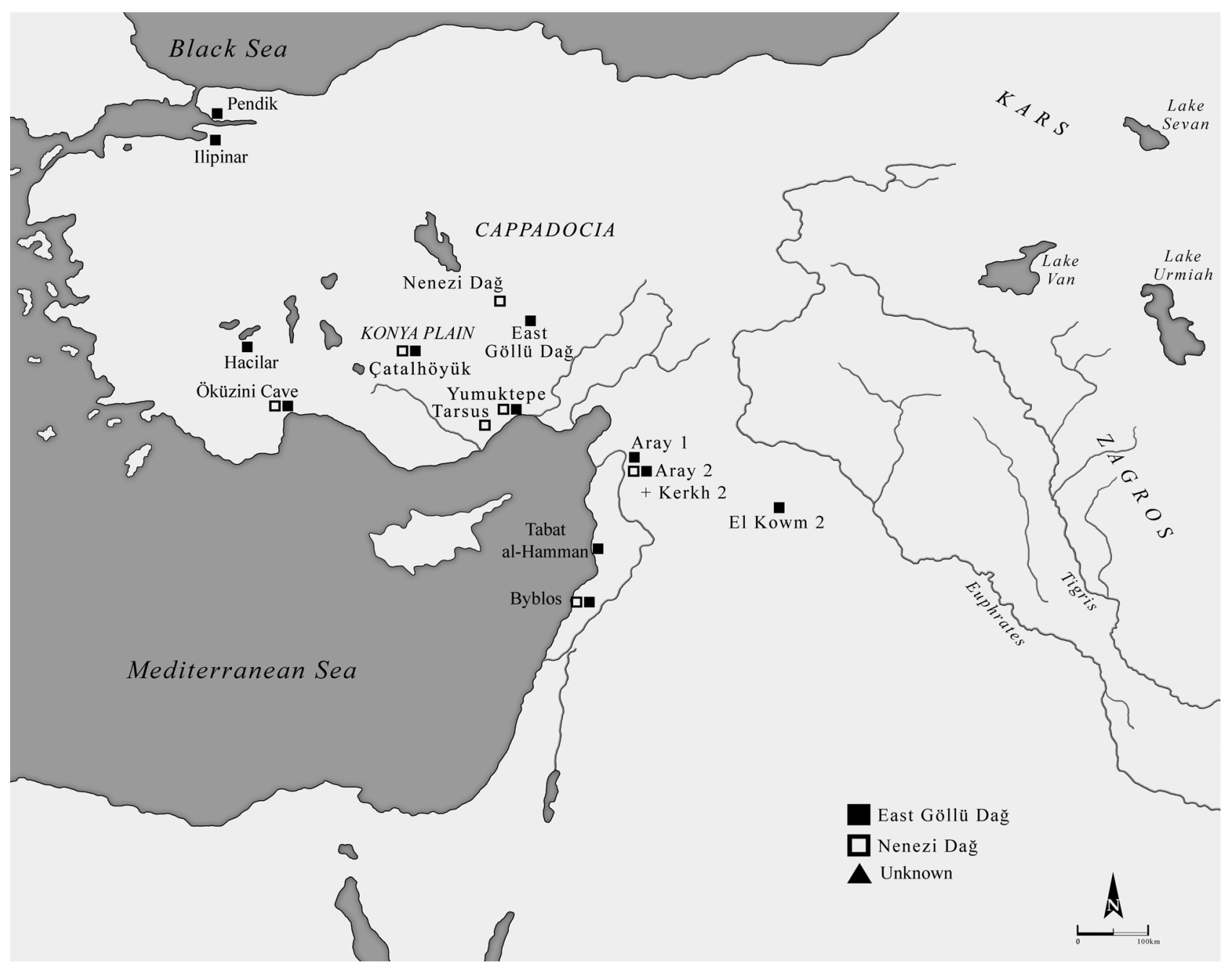

Fig. 10 - Distribution of Cappadocian obsidian in Period 6 (Late Neolithic) (M. Milić).

exhausted bladelet core (ÖC 27 [fig. 5: e]), plus four bladelet fragments (ÖC 15, ÖC 31, ÖC 38 and ÖC 55 [fig. 5: f-g]), all of which were made of Nenezi Dağ obsidian. Technologically there is no reason why this material could not be residual material from Epi-Palaeolithic strata, though one notes that the raw material is different to that of the bladelets from GH Ia2.

Primarily on the basis of the one radiocarbon date and the tanged point we are tempted to date GH Ib1 to the Late Neolithic in central / south-western Anatolian terms, equating broadly with the Maison de l'Orient's Period 6, i.e. the second half of the $7^{\text {th }} /$ first half of the $6^{\text {th }}$ millennia cal. BC. ${ }^{90}$ During this period obsidians from East Göllü Dağ and Nenezi Dağ

90. Aurenche et al., 2001: 1197-1198. are known to have circulated amongst communities throughout Anatolia and the Levant (fig. 10). In central Anatolia these Cappadocian obsidians represented the primary chipped stone raw material for such Late Neolithic communities as Çatalhöyük East in the Konya Plain and Yumuktepe/Mersin on the Cilician coast ( $c a 97 \%$ and $86 \%$ respectively). ${ }^{91}$ Once again, as one moves south/south-west of the Konya Plain the amount of obsidian in circulation appears to fall off rapidly. That said, it represents $42 \%$ of the chipped stone raw materials at Late Neolithic / Early Chalcolithic Hacılar, with ample evidence for its on-site reduction, ${ }^{92}$ yet this Lake District site

91. Carter et al., 2006; Renfrew et al., 1966: 60 (Yümüktepe/Mersin - Level XXIV).

92. Mortensen, 1970. 
is further on from the sources than the Öküzini Cave, where obsidian once more comprises only a tiny proportion of the assemblage $(<1 \%)$. Farther afield, East Göllü Dağ obsidian has also been documented at Late Neolithic Ilıpınar and Pendik in northwest Anatolia, El Kowm (Syria), Byblos and Tabatel-Hammam on the Levantine littoral, plus Aray 1, Aray 2 and Kerkh 2 in the Rouj Valley (NE Syria), while Nenezi Dağ products are documented from a few of the same sites, specifically Çatalhöyük East, Yumuktepe/Mersin Byblos, Aray 2 and Kerkh $2 .{ }^{93}$

\section{GH 0 - EARLY-LATE CHALCOLITHIC (EARLY- MIDDLE HOLOCENE) - PERIODS 9-10}

GH 0 represents the Öküzini Cave's uppermost deposits, containing material culture of later prehistoric, Roman and modern date. The earliest material relates to a small Early-Late Chalcolithic burial ground (fig. 2), with five graves radiocarbon dated to the $5^{\text {th }}-4^{\text {th }}$ millennia cal. BC (tables $2-3$ ). ${ }^{94} \mathrm{GH} 0$ constitutes the excavators' cultural Phase VI (fig. 3-4), spans the Early-Middle Holocene and can be equated with the Maison de l'Orient's Periods 9-10.95

The nature of the GH 0 chipped stone assemblage is described above. Half of the Öküzini Cave obsidian came from these latest strata $(\mathrm{n}=29,23.43$ grams $),{ }^{96} 17$ of which were sourced to Nenezi Da and 12 to East Göllü Da (table 3). All but one came from the eastern part of the cave where the graves were located. One tiny flake (ÖC 16) actually came from the fill of a Late Chalcolithic burial (Grave II), ${ }^{97}$ but is not considered an actual grave good. As before, most of the artefacts are small and fragmentary, with many chronologically undiagnostic. While almost a third of this material is described as 'non-cortical flakes' ( $n=9)$, many of these pieces are probably highly fragmented bladelets (only one of these 'flakes' was complete). Indeed the rest of the assemblage is almost entirely made up of blades and bladelets $(n=13)$, nine of Nenezi Dağ obsidian and four of East Göllü Dağ (fig. 5: i-o). The longest - near complete - example was made of East

93. Bigazzi et al., 1998: 82-86; Carter et al., 2006; Gale, 1981; Maeda, 2003; Renfrew et al., 1966.

94. Seven radiocarbon dates were generated in total, but one from the $10^{\text {th }}$ millennium cal. BC was obviously residual while another of AD 1297 was patently intrusive (Kartal and Erek, 2002).

95. López Bayón, Léotard et Kartal, 2002: 33, 37, fig. 3a-b, 4a-b.

96. This figure includes three pieces labelled as 'GH 0-I': ÖC 32, ÖC 33 and ÖC 56.

97. Dated to the late $4^{\text {th }}$ millennium cal. BC by radiocarbon sample RT-3892 (Kartal and Erek, 2002: 347-349).
Göllü Dağ obsidian and measured $1.86 \mathrm{~cm}$ long (ÖC 28 [fig 5: j]); two of the Nenezi Dağ pieces were retouched, one having simple linear modification (ÖC 08 [fig. 5: 1]), while the other was notched (ÖC 20 [fig. 5: m]). Given that Anatolian Chalcolithic assemblages tend to comprise true unipolar prismatic blade products, ${ }^{98}$ it is not inconceivable that these are Epi-Palaeolithic bladelets re-deposited from earlier strata when the graves were dug. Alongside the bladelets were four blades that we consider genuine Chalcolithic (or Late Neolithic) products, not least ÖC 13 and ÖC 23, medial blade segments that had been retouched into trapezoidal transverse projectiles, the former's raw material sourced to Nenezi Dağ, the latter to East Göllü Dağ (fig. 5: k). A handful of these distinctive implements made of radiolarite are recorded from the upper layers at the Öküzini Cave, Type 43 in Kartal's microlith typology (albeit made on flakes), while examples made on blades are known from Holocene layers at the nearby Karain $\mathrm{B}^{99}$ and Suluin caves. ${ }^{100}$ Trapezes made on blades seem to be a relatively common later Neolithic / Chalcolithic tool type, with examples known from Early Chalcolithic Yumuktepe/Mersin in Cilicia and Çatalhöyük West in the Konya Plain (6 $6^{\text {th }}$ millennium cal. BC), ${ }^{101}$ from Fikirtepe Culture sites of NW Anatolia (later $7^{\text {th }}$ $6^{\text {th }}$ millennia cal. BC),${ }^{102}$ while in the Near East they are most popular during the late $5^{\text {th }}$ and $4^{\text {th }}$ millennia cal. BC..$^{103}$

The fact that the inhabitants of the Öküzini Cave continued to use East Göllü Dağ and Nenezi Dağ products during the Chalcolithic comes as no surprise, for while an expanded range of obsidians are known to have come into play at this time ${ }^{104}$ these clearly remained the primary sources in central Anatolia, with a major quarry-based atelier at KaletepeKömürcü at this time (fig. 1). ${ }^{105}$ For central Anatolian communities of the period obsidian remained the primary raw material for chipped stone tool production, dominating the assemblages at Tepecik/Çiftlik Höyük and Köşk Höyük in western Cappadocia, ${ }^{106}$ plus Canhasan I and Çatalhöyük West in the Konya Plain (fig. 11). ${ }^{107}$ At the latter site some of us have been responsible for analysing over 200 artefacts

98. Cf. Carter, Milić, Kayacan et al., 2008; Garstang, 1953: 50-52; Léon Leurquin, 1986; Mortensen, 1970.

99. Kartal, 2002: 240, fig. 20,13.

100. Prof. Dr. Harun Taşkıran, Personal communication.

101. Carter et al., 2007; Conolly, 1999 : 36-37; Garstang, 1953: 50, fig. 29.

102. Özdoğan, 1999: 211-215, fig. 4.

103. Rosen, 1997: 39-44, fig. 3.2.

104. Cf. Bressy et al., 2005; Fornaseri et al., 1975-1977; Khalidi et al., 2009; Renfrew et al., 1966: 48; Yellin et al., 1996.

105. Balkan-Atlı et Binder, 2000: 205.

106. Biçakçı, 2001: 29-30; Öztan, 2002: 59.

107. Though these sites are admittedly earlier in date: French, 1962: 32; Raszick, 2002 and 2003. 


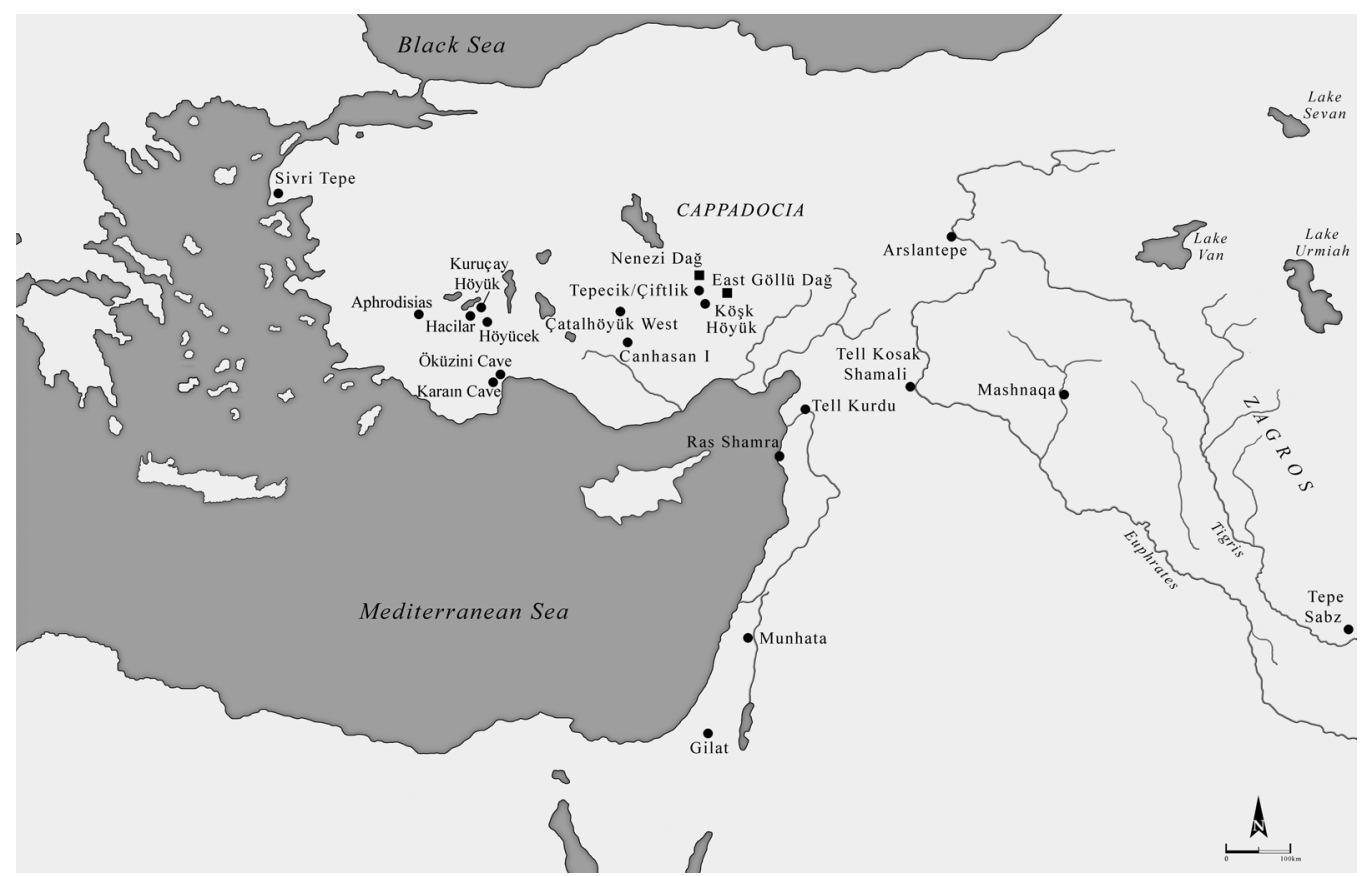

Fig. 11 - Distribution of Cappadocian obsidian in Periods 9-10 (Early-Late Chalcolithic) (M. Milić).

from Early Chalcolithic I-II contexts, virtually all of which were shown to have been made of obsidian from East Göllü Dağ and Nenezi Dağ. ${ }^{108}$ As before, the amount of obsidian in circulation seems to diminish fairly rapidly as one leaves central Anatolia, as for example at Höyücek and Kurucay Höyük in the Lake District, ca 350-390 km west of the Cappadocian sources, where obsidian represents only $10 \%$ and $12-16 \%$ respectively of their Early-Late Chalcolithic chipped stone assemblages. ${ }^{109}$ That said, obsidian comprised $42 \%$ of the late Neolithic-Chalcolithic assemblage at nearby Hacilar, which is located slightly further from the sources (ca $400 \mathrm{~km}$ ), indicating that access to these Cappadocian raw materials was based on more complex factors than proximity to the quarries. ${ }^{110}$ Indeed, in terms of linear distance the Öküzini Cave is somewhat closer to the sources ( $c a 380 \mathrm{~km}$ ),

108. Carter et al., 2006: 907. The sourcing data from a further 200 artefacts are being prepared for publication.

109. This is still considerably more than that we have at the Öküzini Cave, despite being located at much the same distance(s) from the Cappadocian sources (Balkan-Atl1, 2005: 131; Baykal-Seeher, 1994: 106-108, and 1996: 126-127)

110. Mortensen, 1970: 153-154. One notes a similar situation in the Konya Plain, for while $95 \%$ of the chipped stone at Çatalhöyük West is obsidian, it comprises a far smaller proportion of the assemblages from its neighbouring contemporaries (Baird, 2005: 71-73). yet its Chalcolithic assemblage contains a far smaller proportion of obsidian, indicating the inhabitants' existence on the margins of those socio-economic networks through which these Cappadocian raw materials circulated. One might view these data as contributing further to the recent view that the Antalya region communities were located in a somewhat marginal position vis-à-vis the major 'cultural zones' of the period, ${ }^{111}$ and further evidence for the lack of strong links between the inhabitants of the Antalya region and those living in the Lake District / Konya Plain. ${ }^{112}$

Returning to the wider evidence for the use of the two main southern Cappadocian sources during the Early-Late Chalcolithic (fig. 11), archaeometric analyses have recorded East Göllü Dağ from such broadly contemporary sites as the South-Eastern Turkish settlements of Tell Kurdu (HalafUbaid) and Arslantepe (Halaf), ${ }^{113}$ Ras Shamra and Tell Kosak Shamali in Syria, Gilat and Munhata in Israel, plus Mashnaqa and Tepe Sabz in Mesopotamia, the latter over $1200 \mathrm{~km}$ from the source. ${ }^{14}$ In the other direction, the same obsidian is

111. Schoop, 2005: 17-20, fig. 1.1 .

112. Cf. Kayan et al., 1987.

113. Bressy et al., 2005; Fornaseri et al., 1975-1977.

114. Bellot-Gurlet et al., 2003; Chataigner, 1998 : 290-291; Renfrew et al., 1966: 48; Wright and Gordus, 1969; Yellin et al., 1996. 
attested at both Late Chalcolithic Sivri Tepe in the Troad, ${ }^{115}$ and Late Chalcolithic Aphrodisias in SW Turkey where products from Nenezi Dağ were also attested. ${ }^{116}$

\section{DISCUSSION}

In summary, all of the obsidian analysed from the Öküzini Cave comes from the southern Cappadocian sources of East Göllü Dag and Nenezi Dağ, with the latter's recovery from GH VIII and GH Ia2 serving to push back the earliest evidence of this raw material's long-distance use by some eight millennia. The Nenezi Dağ component of the Öküzini Cave material is important not only for its early date, but also because it dominates the overall assemblage. This is in marked contrast to what one has come to expect from Eastern Mediterranean prehistoric sites, where previous characterisation studies had showed that East Göllü Dağ obsidian was both the first and quantitatively most important of the Cappadocian sources. ${ }^{117}$ So why does the Öküzini Cave data not conform to the existing pattern? We would argue that there are two issues of concern here. The first is perhaps the most significant, namely that our results have arguably shed light on a different set of socio-economic practices to those engaged in by contemporary huntergatherers groups to the east of Cappadocia. The idea that different peoples over such large areas were exploiting distinct obsidian sources should not perhaps be surprising; at the same time, this data might be an important reflection of how various populations employed common resources as a means of selfidentification and association with and / or distinction from other groups. It is very much hoped that the planned characterisation of obsidian from the late Epi-Palaeolithic / Aceramic Neolithic sites of Pinarbaşı and Boncuklu in the Konya Plain will help us further clarify these matters.

The second point to make concerning the relative quantity of Nenezi Dağ obsidian at the Öküzini Cave, is that parts of the assemblage might in fact be quite typical for their period, namely that from the Late Neolithic and Chalcolithic strata. If one surveys the extant sourcing data one appreciates quite rapidly that there has been something of a research bias towards Epi-Palaeolithic and Aceramic Neolithic sites, with far less attention accorded to obsidian assemblages from Pottery Neolithic and later prehistoric sites. Thus the dominance of

115. Pernicka et al., 1996

116. Blackman, 1986

117. Chataigner, 1998; Cauvin et Chataigner, 1998.
East Göllü Dağ obsidian in the Eastern Mediterranean might in fact relate to certain periods but not all. Indeed recent work at Çatalhöyük has demonstrated clearly that these two Cappadocian sources had a quite different history of use for this Konya Plain community. Here a combination of archaeometric analyses and visual discrimination studies indicate that East Göllü Dağ products are dominant (up to 95\%) in the Aceramic Neolithic and earliest Early Ceramic Neolithic strata (Level Pre XII.D - VIB), after which there is a radical shift to a reliance upon Nenezi Dağ obsidian (Level VIA - I [again as much as 95\%]), while Early Chalcolithic assemblages tend to be quite evenly balanced between the two. ${ }^{118}$ When considered in this light, the Öküzini Cave data set finds itself far less anomalous, providing further evidence for a radical reconfiguration of Cappadocian source exploitation (for certain communities) somewhere around the middle of the $7^{\text {th }}$ millennium cal. BC, if the Çatalhöyük data is ultimately to prove to be representative of a larger whole.

In trying to reconstruct the form(s) in which these obsidians were procured by the cave's inhabitants, we are hampered by the fact that most of the artefacts had been rendered technologically and typologically undiagnostic due to intensive reduction/curation processes, arguably a reflection of the material's rarity. With no cortical material we can at least say that the cave's occupants gained access to this material in an already worked state, conceivably as finished products, bladelets during the Epi-Palaeolithic, then blades and projectiles in later periods. Nor can we say a great deal about how these implements were used or valued, as they all came from general fill deposits. As such, our discussion of the Öküzini Cave material has had to focus on contextualising the material within the broader history of these Cappadocian obsidians use by prehistoric populations in Anatolia and the Near East. We here provide some further thoughts as to the socioeconomic significance of this material to those who lived at the site.

Given that deposits spanning 11 millennia have produced a mere 56 pieces of obsidian, it is clear that obsidian would have represented a highly exotic material to the cave's inhabitants throughout its occupation history. Entire generations likely never experienced its procurement and use. So what was the significance of this material to these people and what can be said more generally about this handful of material? In trying to explain why only such small quantities of obsidian made their way to the Öküzini Cave we think most people would empha-

118. Carter et al., 2006; Carter and Shackley, 2007; Poupeau et al., 2010; T. Carter, personal observation. 
sise two facts: 1) the great distances between the site and the obsidian sources, and 2) the site's rich local ecology with its plentiful supplies of good quality lithic raw materials.

Considering the first point, we would argue that concepts of distance are culturally constructed and as such are not constant. ${ }^{119}$ In our study we are dealing with very different groups of people, from Epi-Palaeolithic hunter-gatherers via Neolithic farmers to a Late Chalcolithic populace who were on the margins of a world that was experiencing not only early metallurgy, but also the emergence of proto-urbanism. ${ }^{120}$ Each of these societies was underpinned by a variety of socio-economic relations that involved resources, material culture and ideas moving over significantly different distances, whereby the Öküzini Cave data has to be considered within its particular chronological / cultural milieu.

The earliest material from the Öküzini Cave (GH VIII and GH Ia2) arguably fits the pattern of what one sees in later Palaeolithic Europe more generally; i.e. that while the chipped stone assemblage contains the occasional piece from over $300 \mathrm{~km}$ away, most of the tools were made of resources available within a $100 \mathrm{~km}$ radius. ${ }^{121}$ Previous work in the Near East has seen no reason to invoke formal trade mechanisms at such an early date to explain the movement of such long-distance 'exotica'. The tiny quantities of obsidian recovered from these early sites are thought to reflect opportunistic procurement by hunter-gatherers who operated within large shifting territories. ${ }^{122}$ While we do not rule out this model as a means of explaining the few pieces of obsidian from Epi-Palaeolithic strata, we do wonder if the distances involved in the case of the Öküzini Cave might not equally suggest the material's sporadic movement through simple forms of exchange. The data from the later Epi-Palaeolithic (Natufian) Levant, broadly contemporary with the GH Ia2 material, arguably supports this hypothesis, as here we have instances of East Göllü Dağ obsidian being found $500 \mathrm{~km}$ from source (at Ain Mallaha in central Israel), ${ }^{123}$ the procurement of which must have involved a process of down-the-line movement via intermediary communities (fig. 9).

For later periods, the procurement and circulation of obsidian are viewed in more complex terms. The model that has

119. Cf. Helms, 1988.

120. Algaze, 2005.

121. Gamble, 1999: 313-315. See also Demars, 1998; Geneste, 1988.

122. Renfrew et al., 1966: 50.

123. Delerue et Poupeau, 2007. Obsidian has also been found at Natufian Shunera in southern Israel, though this material has yet to be analysed; if it came from central or eastern Anatolia it would represent a movement of over $800 \mathrm{~km}$ from source (Cauvin et Chataignier, 1998: 330-331). underpinned our conceptualisation of exchange in Neolithic and Chalcolithic Anatolia / the Near East is that proposed by Colin Renfrew and colleagues over 40 years ago, based on the results of their groundbreaking, large-scale sourcing programme. ${ }^{124}$ Their analysis of the distribution patterns associated with Cappadocian and south-eastern Anatolian obsidians led them to argue that two modes of exchange existed in parallel, the primary influence in both instances being distancefrom-source. It was proposed that those who lived close to the obsidian quarries would have procured the raw materials themselves with no need for formal mechanisms of exchange, a notional region that was termed the 'supply zone'. At a distance of approximately $250-350 \mathrm{~km}$ from source it was noted that the amount of obsidian in circulation decreased exponentially, a change in distribution patterns that was interpreted as reflecting the shift from communities with 'direct access' to obsidian to those who were reliant upon intermediary exchange networks. ${ }^{125}$ Given that the Öküzini Cave is located in this more distant 'contact zone', one could argue that it should come as no surprise that so little obsidian reached the site. However, we would argue that the quantities recovered from the cave do not fit this hypothetical pattern. For instance we have noted above the striking contrast between the Öküzini Cave and Hacilar data, the latter having $42 \%$ of its Late Neolithic/ Early Chalcolithic chipped stone consisting of obsidian despite the fact that this community is situated further from the sources than our cave site (fig. 10-11). This suggests strongly that access to these Cappadocian raw materials was not based on issues of distance alone; instead we would argue that it has more to do with the fact that these people were located on the margins of those socio-economic networks through which these obsidians circulated.

In thinking further about this notion of marginality we need to turn to the issue of the rich local ecology. It has to be admitted that a strong case can be made that a certain cultural insularity developed amongst the prehistoric people of the Antalya region due to the "plentiful possibilities of living" offered by their Mediterranean coastal environment, ${ }^{126}$ not least their locally available artefact quality stone. Such plentiful resources may indeed have led to the development of a more restricted territory and worldview. Indeed, we have already noted the limited communication that existed between the later Epi-Palaeolithic hunter-gatherers of this region and their obsidian using contemporaries living to the north-east

124. Renfrew et al., 1966 and 1968.

125. Renfrew, 1968: 326-331.

126. Bostanc1, 1962: 267. 
in the Konya Plain (during the period represented by strata GH Ia1 - Ia2).

In a situation perhaps analogous to the 'Mesolithic paradise' offered by the location of Serbia's famed Lepenski Vir, there is evidence to suggest that a hunter-gatherer lifestyle was retained by these Antalya region communities long after farming economies had been adopted by those living in the surrounding areas of Cilicia, the Konya Plain and Lake District. ${ }^{127}$ At this point it is tempting to view the limited amounts of obsidian being procured by the cave's inhabitants in terms of a genuine hunter-gatherer / farmer frontier. Here we focus on the long-acknowledged fact that the trade and use of obsidian is a quintessentially Neolithic phenomenon. ${ }^{128}$ This is not to reduce the material significance to a farming-related functionality, but instead to highlight the idea that its consumption formed an important part of the Neolithic mentalité, not least through its recurrent inclusion in the acts of exchange that bound these communities together and a variety of related symbolically charged practices. ${ }^{129}$

The late Epi-Palaeolithic occupants of the Öküzini Cave were contemporaries of these early agriculturalists, and we would suggest that it was these fundamental lifestyle differences that represented the greatest barrier to these people's procurement of obsidian, rather than distance from source. In evoking the hunter-gatherer / farmer frontier, we are careful to emphasise a temporal and geographical specificity, as opposed to a belief that this opposition is somehow inherently significant, ${ }^{130}$ hence our previous distinction between central / south-western Anatolian Epi-Palaeolithic populations. In due course the peoples of the Antalya region appear to have adopted true agro-pastoral lifestyles, ${ }^{131}$ yet we would suggest that the prehistoric inhabitants of this region never really shook off their earlier heritage in terms of their restricted access to the 'Neolithic' exchange networks of Central / South-central Anatolia; a regional difference remained.

We thus find it significant that amongst the few typologically distinctive obsidian artefacts from the later prehistoric levels at the Öküzini Cave are three arrowheads. We suggest that what we are primarily witnessing here is the movement of socially meaningful goods, i.e. the exchange of hunting equip-

127. Garasanin and Radovanovic, 2001.

128. Cauvin, 2000: 93-94.

129. Cf. Carter, 2007, and for the circulation of large projectile preforms see Balkan-Atlı et Der Aprahamian, 1998: 244, fig. 6.

130. Cf. Baird, 2007b: 294-295.

131. An argument largely based on the presence of recognisable 'Neolithic' and 'Chalcolithic' material culture as opposed to a detailed report upon the archaeobotanical and faunal assemblages of the period. ment / weaponry, rather than the movement of raw materials alone. One could easily imagine that a projectile would represent an appropriate item for gifting, particularly if the hafting and fletching was indicative of a particular individual or social group ${ }^{132}$ these objects initially flowing — albeit rarelyacross a regional-cultural boundary that seems to have continued in various forms from the early Epi-Palaeolithic to the Late Chalcolithic, with the Öküzini Cave' perpetual marginal location restricting its inhabitants' access to the black gold of Cappadocia.

\section{ACKNOWLEDGEMENTS}

This project would not have been possible without the permission of the excavation directors Işin Yalçınkaya and Marcel Otte for access to the material and the Turkish Ministry of Culture for the permit to export the obsidian for analyses. Ofer Bar-Yosef, Marcel Otte and Ignacio López Bayón provided invaluable advice and insight to the Öküzini Cave's occupation sequence and absolute dating. We are also grateful to Harun Taşkıran, and Catriona Gibson and Rebecca Williams for access to unpublished data, leads on literature and critical feedback, plus Danica Mihailović and Marina Milić for the map and line illustrations. Laurent Pichon and the late Joseph Salomon facilitated our analyses of the samples at AGLAE. Carter's time working on the Öküzini Cave material at Ankara University was undertaken while a Post-Doctoral Fellow of the British Institute at Ankara, while his contribution to the final stages of the paper were undertaken at CRP2A thanks to a grant from the Scientific Service, French Embassy in Canada (2008). Finally we gratefully acknowledge the critical reflections and aid of our two anonymous reviewers and the Paléorient editorship.

Tristan CARTER Department of Anthropology, CNH 524 McMaster University, 1280 Main Street W Hamilton, Ontario L8S $4 L 9$ - CANADA stringy@mcmaster.ca

François-Xavier LE BOURDONNEC et Gérard POUPEAU

IRAMAT-CRP2A, UMR 5060 CNRS-Université Bordeaux 3, Maison de l'Archéologie Esplanade des Antilles 33607 Pessac - FRANCE francois-xavier.le-bourdonnec@u-bordeaux3.fr gроиреаи@mnhn.fr

Metin KARTAL

Department of Archaeology, Faculty of Letters Ankara University, 06100 Sihhiye - TURKEY kartal@humanity.ankara.edu.tr

132. Cf. Akerman et al., 2002; Ataman, 1998: 266-269; Bayman, 1995: 53-54; Wiessner, 1983: 260-261. 
Thomas CALLIGARO

Centre de Recherche et de Restauration des Musées de France, UMR CNRS 171

14 Quai François Mitterrand 75001 Paris - FRANCE

thomas.calligaro@culture.fr
Philippe MORETTO

Centre d'études nucléaires de Bordeaux-Gradignan UMR 5797, CNRS-Université Bordeaux 1 Chemin du Solarium, Le Haut Vigneau BP 120 33175 Gradignan Cedex - FRANCE moretto@cenbg.in2p3.fr

\section{BIBLIOGRAPHY}

ABBÈs F., BALKAN-ATLI N., BINDER D. and CAUVIN M.-C.

1999 Gestion de la matière première et économie du débitage. Rapport préliminaire sur l'industrie d'Aşıklı. Tüba-Ar 2: 117-137.

AbBÈs F., Bellot-Gurlet L., Bressy C., CAUVin M.-C., GratuZe B. et POUPEAU G.

2001 Nouvelles recherches sur l'obsidienne de Cheikh Hassan (Vallée de l'Euphrate, Syrie) au Néolithique PPNA et PPNB. Syria 78 : 1-13.

AbBÈs F., Bellot-Gurlet L., CAUvin M.-C., Delerue S., DUBERnET S., POUPEAU G. and STORDEUR D.

2003 Provenance of the Jerf el Ahmar (Middle Euphrates Valley, Syria) obsidians. Journal of Non-Crystalline Solids 323: 162166.

AKERMAN K., FULLAGER R. and VAN GIJN A.

2002 Weapons and wunan: production, function and exchange of Kimberley points. Australian Aboriginal Studies 2002(1): $13-42$.

ALBRECHT G.

1988 Preliminary results of the excavation in the Karain B cave near Antalya / Turkey: The Upper Palaeolithic assemblages and Upper Pleistocene climatic development. Paléorient 14,2: 211222.

1991 Das spätpaläolithische Station Öküzini bei Antalya (Türkei). Bericht unter die 1989 durchgeführte Sondage. Mitteilungsblatt der Archaeologica Venatoria E.V. 16: 7-19.

Albrecht G., Albrecht B., BERKe H., Burger D., MOSER J.,

RÄHLE W., SCHOCH W., STORCH G., UERPMANN H. P. and URBAN B.

1992 Late Pleistocene and Early Holocene finds from Öküzini: A contribution to the settlement history of the Bay of Antalya, Turkey. Paléorient 18,2: 123-141.

ALGAZE G.

2005 The Uruk World System: The Dynamics of Expansion of Early Mesopotamian Civilization [ ${ }^{\text {nd }}$ edition]. Chicago: University of Chicago Press.

ATAMAN K.

1988 The Chipped Stone Assemblage from Can Hasan III: A Study in Typology, Technology and Function. Unpublished PhD Thesis. London, University College Institute of Archaeology.

ATICI A.L. and STUTZ A.

2002 Analysis of the ungulate fauna from Öküzini: A preliminary reconstruction of site use, seasonality and mortality patterns. In: YALÇINKAYA et al. (éd.): 101-108.
AURENCHE O., GALET P., RÉGAGNON-CAROLINE E. and ÉVIN J.

2001 Proto-Neolithic and Neolithic cultures in the Middle East - the birth of agriculture, livestock raising, and ceramics: A calibrated ${ }^{14} \mathrm{C}$ chronology 12,500-5500 cal BC. Radiocarbon 43,3: 1191-1202.

BAIRD D.

2002 Early Holocene settlement in Central Anatolia: problems and prospects as seen from the Konya Plain. In: GÉRARD F. and THISSEN L. (eds.), The Neolithic of Central Anatolia: Internal Developments and External Relations during the $9^{\text {th }}-6^{\text {th }}$ Millennia Cal BC: 139-152. Istanbul: Ege Yayinları.

2005 The history of settlement and social landscapes in the Early Holocene in the Çatalhöyük area. In: HODDER I. (ed.), Çatalhöyük Perspectives: Reports from the 1995-99 Seasons: 55-74. Cambridge: McDonald Institute Monographs, and London: British Institute at Ankara (monograph 40).

2007a The Boncuklu Project: the origins of sedentism, cultivation and herding in central Anatolia. Anatolian Archaeology 13: 14-18.

2007b Pinarbaşı. Orta Anadolu'da Epi-Paleolitik Konak Yerinden Yerlesik Köy Yaşamına. In: ÖZDOĞAN M. and BAŞGELEN N. (eds.), Türkiye'de Neolitik Dönem: 285-311. Istanbul: Arkeoloji ve Sanat Yayınları.

2008 The Boncuklu Project: the origins of sedentism, cultivation and herding in central Anatolia. Anatolian Archaeology 14: 11-12.

\section{BALKAN-ATLI N.}

1998 The Aceramic Neolithic of Central Anatolia: recent finds in the chipped stone industry. In: ARSEBÜK G., MELlinK M.J. and SCHIRMER W. (eds.), Light on Top of the Black Hill. Studies Presented to Halet Çambel: 81-94. Istanbul: Ege Yayınları.

2005 Yontmataş endüstrisi. In: DURU R. and UMURTAK G., Höyücek. Results of the Excavations 1989-1992: 130-137. Ankara: Türk Tarih Kurumu Yayınları.

BALKAN-ATLI N. et BINDER D.

2000 L'atelier néolithique de Kömürcü-Kaletepe: fouilles de 1999. Anatolia Antiqua VIII: 199-214.

BALKAN-ATLI N. et DER APRAHAMIAN G.

1998 Les nucléus de Kaletepe et deux ateliers de taille en Cappadoce. In : CAUVIN et al. (éd.) : 241-257.

BAR-YOSEF O. and BELFER-COHEN A.

1989 The Levantine 'PPNB' Interaction Sphere. In: HERSHKOVITZ I. (ed.), People and Culture in Change: 59-72. Oxford (BAR Int. Ser. 508). 


\section{BAYKAL-SEEHER A.}

1994 Silex und obsidian industrien. In: DURU R. (ed.), Kuruçay Höyük I: Results of the Excavations 1978-1988. The Neolithic and Early Chalcolithic Periods: 106-108. Ankara: Türk Tarih Kurumu Basımevi.

1996 Silex und obsidian industrien. In: DURU R. (ed.), Kuruçay Höyük II: Results of the Excavations 1978-1988. The Late Chalcolithic and Early Bronze Age Settlements: 126-127. Ankara: Türk Tarih Kurumu Basımevi.

\section{BAYMAN J.M.}

1995 Rethinking 'redistribution' in the archaeological record: Obsidian exchange at the Marana Platform Mound. Journal of Anthropological Research 51,1: 37-63.

BELlot-GuRlet L., POUPEAU G. and BRESSY C.

2003 Element contents determined by ICP-AES and ICP-MS at Grenoble on nine obsidian artefacts from Tell Kosak Shamali: Results and inference on provenance. In: NISHIAKI Y. and MATSUTANI T. (eds.), Tell Kosak Shamali Vol II: The Archaeological Investigations on the Upper Euphrates, Syria. Chalcolithic Technology and Subsistence: 113-115. Tokyo, Oxford: Oxbow Books / The University Museum.

BIALOR P.

1962 The chipped stone industry of Çatal Hüyük. Anatolian Studies XII: 67-110.

BIÇAKÇI E.

2001 Tepecik/Çiftlik Höyü̆ğ (Niğde) kazısı ısığında Orta Anadolu tarihöncesi kültürleri ile ilgili yeni bir değerlendirme. $T \ddot{U} B A$ AR 4: 25-41.

BigaZZI G., POUPEAU G., BELlot-GURLET L. and YeZINGILI Z.

1998 Provenance studies of obsidian artefacts in Anatolia using the fission-track dating method: an overview. In: CAUVIN M.-C. et al. (éd.): 69-89.

BINDER D.

2002 Stones making sense: what obsidian could tell us about the origins of the Central Anatolian Neolithic. In: GÉRARD F. and THISSEN L. (eds.), The Neolithic of Central Anatolia: Internal Developments and External Relations during the $9^{\text {th }}-6^{\text {th }}$ millennia cal BC: 279-285. Istanbul: Ege Yayınlar1.

BINDER D. and BALKAN-ATLI N.

2001 Obsidian exploitation and blade technology at Kömürcü-Kaletepe (Central Anatolia). In: CANEVA I., LEMORINI C., ZAMPETTI D. and BIAGGI P. (eds.), Beyond Tools. Redefining the PPN Lithic Assemblages of the Levant. Proceedings of the Third Workshop on PPN Chipped Lithic Industries, Venice, 1998: 1-16. Berlin: ex Oriente (SENEPSE 9).

BINFORD L.R.

1979 Organization and formation processes: looking at curated technologies. Journal of Anthropological Research 35: 255-273.

BLACKMAN M.J.

1986 The provenience of Obsidian Artifacts from Late Chalcolithic levels at Aphrodisias. In: JoUKOWSKY M. (ed.), Prehistoric Aphrodisias: An Account of the Excavations and Artifact Studies: 279-285. Providence, RI, and Louvain-la-Neuve (Archaeologia Transatlantica III).

\section{BOSTANCI E.Y.}

1962 A new Upper Palaeolithic and Mesolithic facies at Belbaşı rock shelter on the Mediterranean Coast of Anatolia. Belleten 26: 252-292.

BRESSY C., POUPEAU G. and YENER K.A.

2005 Cultural interactions during the Ubaid and Half periods: Tell Kurdu (Amuq Valley, Turkey) obsidian sourcing. Journal of Archaeological Science 32: 1560-1565.

BRIOIS F., GRATUZE B. et GUILAINE J.

1997 Obsidiennes du site néolithique précéramique de Shillourokambos. Paléorient 23,1: 95-112.

\section{CALligaro T., MACARTHUR J.D. and SALOMON J.}

1996 An improved experimental setup for the simultaneous PIXE analysis of heavy and light elements with a $3-\mathrm{MeV}$ proton external beam. Nuclear Instruments and Methods in Physics Research Section B 109/110: 125-128.

Calligaro T., DRan J.-C., Moignard B., Pichon L., Salomon J. and WALTER P.

2002 Ion beam analysis with external beams: Recent set-up improvements. Nuclear Instruments and Methods in Physics Research Section B 188: 135-140.

CAMPBELl J.L., HOPMAN T.L., MAXWELl J.A. and NEJEDLY Z.

2000 The Guelph PIXE software package III: Alternative proton database. Nuclear Instruments and Methods in Physics Research B 170: 193-204.

CARTER T.

2007 Of blanks and burials: hoarding obsidian at Neolithic Çatalhöyük. In: ASTRUC L., BINDER D. and BRIOIS F. (eds.), Technical Systems and Near Eastern PPN Communities. Proceedings of the $5^{\text {th }}$ International Workshop, Fréjus, 2004: 343355. Antibes: Éditions APDCA.

2009 L'obsidienne égéenne: caractérisation, utilisation et culture. In: MONCEL M.-H. et FRÖHLICH F. (éd.), L’Homme et le précieux. Matières minérales précieuses de la Préhistoire à aujourd'hui: 199-212. Oxford (BAR Int. Ser. 1934).

CARTER T. and Kilikoglou V.

2007 From reactor to royalty? Aegean and Anatolian Obsidians from Quartier Mu, Malia (Crete). Journal of Mediterranean Archaeology 20,1: 115-143.

CARTER T. and SHACKLEY M.S.

2007 Sourcing obsidian from Neolithic Çatalhöyük (Turkey) using Energy Dispersive X-ray Fluorescence. Archaeometry 49,3: 437-454.

CARTER T., CONOlly J. and SPASOJEVić A.

2005 The chipped stone. In: HODDER I. (ed.), Changing Materialities at Çatalhöyük: Reports from the 1995-99 Seasons: 221-283 and 467-533. Cambridge: McDonald Institute Monographs, and London: British Institute at Ankara (monograph 39).

CARTER T., Milić M. and DOHERTY C.

2007 Chipped stone report. Çatalhöyük 2007 Archive Report. http://www.catalhoyuk.com/downloads/Archive_ Report_2007.pdf 
Carter T., Poupeau G., Bressy C. and Pearce N.J.G.

2005 From chemistry to consumption: towards a history of obsidian use at Çatalhöyük through a programme of inter-laboratory trace-elemental characterization. In: HODDER I. (ed.), Changing Materialities at Çatalhöyük: Reports From the 1995-99 Seasons: 285-305 and 535-557. Cambridge: McDonald Institute Monographs, and London: British Institute at Ankara (monograph 39).

2006 A new programme of obsidian characterization at Çatalhöyük, Turkey. Journal of Archaeological Science 33,7: 893-909.

CARTER T., MiLIĆ M., KAYACAN N., OSTAPTCHOUK S. and MACDONALD B.L.

2008 Chipped stone report. Çatalhöyük 2008 Archive Report. ht tp://www.catalhoyuk.com/downloads/Archive Report_2008.pdf

CARTER T., Dubernet S., King R., LE BourdonneC F.-X., MiLiĆ M., POUPEAU G. and SHACKLEY M.S.

2008 Eastern Anatolian obsidians at Çatalhöyük and the reconfiguration of regional interaction in the Early Ceramic Neolithic. Antiquity 82,318: 900-909.

CAUVIN J.

2000 The Birth of the Gods and the Origin of Agriculture. Cambridge: Cambridge University Press.

CAUVIN M.-C

1991 L'obsidienne au Levant préhistorique: provenance et fonction. Cahiers de l'Euphrate 5-6: 163-190.

Cauvin M.-C., Gourgaud A., Gratuze B., Arnaud N., Poupeau G., POIDEVIN J.-L. et CHATAIGNER C. (éd.)

1998 L'Obsidienne au Proche et Moyen Orient. Du volcan à l'outil. Lyon: Maison de l'Orient Méditerranéen, et Oxford (BAR Int. Ser. 738).

CAUvin M.-C. et Chataigner C.

1998 Distribution de l'obsidienne dans les sites archéologiques du Proche et Moyen Orient. In: CAUVIN et al. (éd.) : 325-350.

ChatAigner C.

1998 Sources des artefacts néolithiques. In : CAUVIN et al. (éd.) : 273324.

DAVIS M.K., JACKSON T.L., SHACKLEY M.S., TEAGUE T. and HAMPEL J.

1998 Factors Affecting the Energy-Dispersive X-Ray Fluorescence (EDXRF) Analysis of Archaeological Obsidian. In: HACKLEY M.S. (ed.), Archaeological Obsidian Studies: Method and Theory: 159-180. New York: Springer/Plenum Press.

DELERUE S.

2007 L'Obsidienne dans le Processus de Néolithisation du ProcheOrient (12000-6500 av. J.-C.). Thèse de Doctorat, Université Michel de Montaigne-Bordeaux 3.

DELERUE S. et POUPEAU G.

2007 La provenance des obsidiennes du Natoufien final de Mallaha. In: VALLA F. R. et al., Les fouilles de Ain Mallaha (Eynan) de 2003 à 2005 : quatrième rapport préliminaire. Journal of the Israel Prehistoric Society 37: 135-379 [291-296].
DEMARS P.-Y.

1998 Circulation des silex dans le nord de l'Aquitaine au Paléolithique supérieur: l'occupation de l'espace par les derniers chasseurs-cueilleurs. Gallia Préhistoire 40: 1-28.

FORNASERI M., MALPIERI L., PALMIERI A.M. and TADDEUCCI A.

1975-1977 Analysis of obsidians from the Late Chalcolithic levels of Arslantepe (Malatya). Paléorient 3: 231-246.

FRENCH D.H.

1962 Excavation at Can Hasan. First preliminary report, 1961. Anatolian Studies XII: 27-40.

GALE N.H.

1981 Mediterranean obsidian source characterisation by strontium isotope analysis. Archaeometry 23,1: 41-51.

GAMBLE C.

1999 The Palaeolithic Societies of Europe. Cambridge: Cambridge University Press.

GARASANIN M. and RADOVANOVIC I.

2001 A pot in house 54 at Lepenski Vir I. Antiquity 75,287: 118-125.

GARSTANG J.

1953 Prehistoric Mersin. Yümük Tepe in Southern Turkey. The Neilson expedition in Cilicia. Oxford: Clarendon Press.

GENESTE J.-M.

1988 Systèmes d'approvisionnement en matières premières au Paléolithique moyen et au Paléolithique supérieur en Aquitaine. In: OTTE M. (éd.), L'Homme de Néandertal. 8, La mutation: 61-70. Liège (ERAUL 35).

GEORGIADIS M.

2008 The obsidian in the Aegean beyond Melos: An outlook from Yali. Oxford Journal of Archaeology 27,2: 101-117.

GÉRARD F. and THISSEN L. (eds.)

2002 The Neolithic of Central Anatolia: Internal Developments and External Relations during the $9^{\text {th }}-6^{\text {th }}$ millennia cal BC. Proceedings of the International CANeW Table Ronde, Istanbul, 23-24 November 2001. Istanbul: Eye Yayınları.

GOLDBERG P. and BAR-YOSEF O.

2002 Micromorphology of selected samples from Öküzini Cave. In: YALÇINKAYA et al. (éd.): 41-47.

GRATUZE B.

1999 Obsidian characterization by Laser Ablation ICP-MS and its application to prehistoric trade in the Mediterranean and the Near East: sources and distribution of obsidian with the Aegean and Anatolia. Journal of Archaeological Science 26: 869-881.

HELMS M.W.

1988 Ulysses Sail: An Ethnographic Odyssey of Power, Knowledge, and Geographical Distance. Princeton: Princeton University Press.

Hours F., Aurenche O., CAuvin J., CAuvin M.-C., Copeland L. et SANLAVILLE P.

1994 Atlas des Sites du Proche-Orient (14 000-5700 BP). Paris, Lyon (TMO). 
KARTAL M.

2002 The microliths of Öküzini Cave. In: YALÇıNKAYA et al. (éd.): 235-252.

KARTAL M. and EREK C.M.

2002 The burials in Öküzini Cave. In: YALÇINKAYA et al. (éd.): $347-$ 351.

\section{KAYACAN N.}

2003 Chipped stone industry of the Neolithic site of Musular (Cappadocia): preliminary results. Anatolia Antiqua X: 1-10

KAYAN I., MiNZONI-DÉROCHE A. et YALÇINKAYA I.

1987 Prospection préhistorique dans la région d'Antalya. Notice préliminaire. Anatolia Antiqua I: 9-13.

KHALIDI L., GRATUZE B. and BOUCETTA S.

2009 Provenance of obsidian excavated from Late Chalcolithic levels at the sites of Tell Hamoukar and Tell Brak (Syria). Archaeometry 51,6: 879-893.

\section{KÖKTEN I.K}

1963 Die Stellung von Karaïn innerhalb der türkischen Vorgeschichte. Anatolia VII : 59-89.

KÖSEM B.

2002 The macrolithic industry of Öküzini cave. In: YALÇINKAYA et al. (éd.): 253-273.

LAST J.

2005

Pottery from the East Mound. In: HODDER I. (ed.), Changing Materialities at Catalhöyük: Reports From the 1995-99 Seasons: 101-138. Cambridge: McDonald Institute Monographs, and London: British Institute at Ankara (monograph 39).

Le BourdonneC F.-X., DELERUE S., DUbernet S. MORETTO P., CALligaro T., DRAN J.-C. and POUPEAU G.

2005 PIXE characterization of Western Mediterranean and Anatolian obsidians and Neolithic provenance studies. Nuclear Instruments and Methods in Physics Research B 240: 595-599.

LÉON LEURQUIN J.

1986 Chipped stone analysis. In: JouKOWSKY M. (ed.), Prehistoric Aphrodisias: An Account of the Excavations and Artifact Studies: 242-278. Providence, RI, and Louvain-la-Neuve (Archaeologia Transatlantica III).

LÉOTARD J.-M. et LÓPEZ BAYÓN I.

2002 La Grotte d'Öküzini : Étude du matériel lithique. In: YALÇINKAYA et al. (éd.): 109-234.

LÓPEZ BAYÓN I., LÉOTARD J.-M. et KARTAL M.

2002 Séquence stratigraphique de la Grotte d'Öküzini. Remplissage naturel et remplissage anthropique. In: YALÇINKAYA et al. (éd.): 27-39.

LÓPEZ BAYÓN I., LÉOTARD J.-M., KARTAL M. et NOIRET P.

2002 La Grotte d'Öküzini: Chronologie et mode de fonctionnement d'un remplissage (analyse radiométrique, rythme sédimentaire et cycles climatiques). In: YALÇINKAYA et al. (éd.): 49-73.

LugliÈ C., Le BourdonneC F.-X., POUPEAU G., ATZENI E., DUBERNET S., MORETTO P. and SERANI L.

2007 Early Neolithic obsidians in Sardinia (Western Mediterranean): the Su Carroppu case. Journal of Archaeological Science 34: 428-439.
Lugliè C., Le Bourdonnec F.-X., Poupeau G., Congia C.,

MORETTO P., CALligaro T., SANNA I. and DUBERnET S.

2008 Obsidians in the Rio Saboccu (Sardinia, Italy) campsite: Provenance, reduction and relations with the wider Neolithic Tyrrhenian area. C.R. Palevol 7,4: 249-258.

MAEDA O.

2003 Prehistoric Obsidian Distribution in the Rouj Basin. In: IWAZAKI T. and TSUNEKI A. (eds.), Archaeology of the Rouj Basin - A regional study of the transition from village to city in Northwest Syria, Vol. I: 167-184. Ibaraki: University of Tsukuba, Institute of History and Anthropology.

MARSHACK A.

2002 Öküzini: The complexity and variation of the symbolic imagery. In: YALÇINKAYA et al. (éd.): 285-332.

MARTINOLI D.

2004 Food plants use, temporal changes and site seasonality at Epipalaeolithic Öküzini and Karain B caves, southwest Anatolia, Turkey. Paléorient 30,2: 61-80.

MAXWELl J.A., CAMPBELL J.L. and TEESDALE W.J.

1989 The Guelph PIXE software package. Nuclear Instruments and Methods in Physics Research B 43: 218-230.

MOORE A.M.T.

1995 The inception of potting in Western Asia and its impact on economy and society. In: BARNETT W.K. and HOOPES J.W. (eds.), The Emergence of Pottery: Technology and Innovation in Ancient Societies: 39-53. Washington (DC): Smithsonian Institution Press.

2000 Stone and other artifacts. In: MOORE A.M.T., HILLMAN G.C. and LEGGE A.J. (eds.), Village on the Euphrates. From Foraging to Farming at Abu Hureyra: 133-163. Oxford: Oxford University Press.

MORTENSEN P.

1970 Chipped stone industry. In: MELlaART J., Excavations at Hactlar: 153-157. Edinburgh: British Institute of Archaeology at Ankara.

OTTE M., LÓPEZ BAYÓN I., NOIRET P., BAR-YOSEF O., YALÇINKAYA I., KARTAL M. and LÉOTARD J.-M.

2003 Sedimentary deposition rates and Carbon-14: the Epi-palaeolithic sequence of Okuzini Cave (Southwest Turkey). Journal of Archaeological Science 30: 325-341.

OTTE M., YALÇINKAYA I., LÉOTARD J.-M., KARTAL M., BAR-YOSEF O., KOZLOWSKI J., LÓPEZ BAYÓN I. and MARSHACK A.

1995 The Epi-Palaeolithic of Öküzini Cave (SW Anatolia) and its Mobiliary Art. Antiquity 69: 931-944.

ÖZBAŞARAN M. and BUITENHUIS H.

2002 Proposal for a regional terminology for Central Anatolia. In GÉRARD F. and THISSEN L. (eds.), The Neolithic of Central Anatolia: Internal Developments and External Relations during the $9^{\text {th }}-6^{\text {th }}$ millennia cal BC: 67-77. Istanbul: Ege Yayınlar1.

\section{ÖZDOĞAN M}

1999 Northwestern Turkey: Neolithic cultures in between the Balkans and Anatolia. In: ÖZDOĞAN M. and BAŞGELEN N. (eds.), Neolithic in Turkey: The Cradle of Civilization. New Discoveries: 203-224. Istanbul: Arkeoloji ve Sanat Yayınları. 
ÖZTAN A.

2002 Köşk Höyük: Anadolu arkeolojisine yeni katkılar. TÜBA-AR 5: 55-69.

PAWLIKOWSKI M

2002 Determination of sources of raw materials: Results of a field survey in the Burhan River Valley (region of Antalya, Turkey). In: YALÇINKAYA et al. (éd.): 275-276.

PERNICKA E., KELLER J., RAPP G. Jr. and ERCAN T.

1996 Provenance of Late Neolithic and Early Bronze Age obsidian artifacts from the Troad. In: DEMIRCI S., ÖZER A.M. and SUMMERS G.D. (eds.), Archaeometry 94. The Proceedings of the $29^{\text {th }}$ International Symposium on Archaeometry, Ankara, 0206 May 1994: 515-519. Ankara: Tübitak.

POIDEVIN J.-L.

1998 Les gisements d'obsidienne de Turquie et de Transcaucasie : géologie, géochimie et chronométrie. In: CAUVIN et al. (éd.): 105-231.

PoUPEAU G., BIGAZZI G., BELLOT-GURLET L. and Dorighel O.

1998 Fission-track dating of obsidians and archaeology. In: CAUVIN et al. (éd.): 53-67.

Poupeau G., Delerue S., Carter T., De B. Pereira C.E., Miekeley N. and BELLOT-GURLET L.

2005 How homogeneous is the "East Göllü Dağ" (Cappadocia Turkey) Obsidian 'Source' Composition? International Association of Obsidian Studies Bulletin 32: 3-8.

Poupeau G., Le BourdonneC F.-X., CARTER T., DElerue S., SHACKLEY M.S., BARRAT J.A., DUBERnET S, MORETTO P., CAlligaro T., MiliĆ M. and KobAYASHI K.

2010 The use of SEM-EDS, PIXE and EDXRF for obsidian provenance studies in the Near East: A case study from Neolithic Çatalhöyük (central Anatolia). Journal of Archaeological Science 37,11: 2705-2720.

\section{RASZICK T.}

2002 Chipped stone. In: GIBSON C., LAST J., RASZICK T. and FRAME S., Çatalhöyük West Mound study season 2002. Çatalhöyük 2002 Archive Report.

http://www.catalhoyuk.com/archive_reports/2002/ar02_09. html

2003 Obsidian and flint. In: GIBSON C., LAST J. and FrAME S. and RASZICK T., West Mound excavations. Çatalhöyük 2003 Archive Report.

http://www.catalhoyuk.com/archive_reports/2003/ar03_11. html

RENFREW C. and ASPINALl A.

1990 Aegean obsidian and Franchthi Cave. In: JACOBSEN T.W. (ed.), Excavations at Franchthi Cave, Greece. Fascicle 5: 257-279. Bloomington: Indiana University Press.

RENFREW C., DIXON J.E. and CANN J.R.

1966 Obsidian and Early Cultural Contact in the Near East. Proceedings of the Prehistoric Society 32: 30-72.

1968 Further analysis of Near Eastern obsidians. Proceedings of the Prehistoric Society 34: 319-331.
ROSEN S.A.

1997 Lithics After the Stone Age. Walnut Creek: Altamira Press.

SCHOOP U.-D.

2005 Das anatolische Chalkolithikum. Eine chronologische Untersuchung zur vorbronzezeitlichen Kultursequenz im nördlichen Zentralanatolien und den angrenzenden Gebieten. Remshalden: Verlag BA Greiner.

SHELFORD P., HODSON F., COSGROVE M.E., WARREN S.E. and RENFREW C.

1982 The sources and characterisation of Melian obsidian. In: RENFrew C. and WAgSTAFF M. (eds.), An Island Polity: the Archaeology of Exploitation in Melos: 182-191. Cambridge: Cambridge University Press.

SLIMAK L.

2004 Implantations humaines et exploitation des obsidiennes en Anatolie centrale durant le Pléistocène. Paléorient 30,2: 7-20.

SLimaK L., KUHN S.L., Roche H., MOURALis D., Buitenhuis H., BALKAN-ATLI N., BINDER D., KUZUCUOĞLU C. and GUILLOU H.

2008 Kaletepe Deresi 3 (Turkey): Archaeological evidence for early human settlement in Central Anatolia. Journal of Human Evolution 54: 99-111.

SUMmerhayes G.R., BIRD J.R., FUllager R., GOSDEN C., SPECHT J. and TORRENCE R.

1998 Application of PIXE-PIGME to archaeological analysis of changing patterns of obsidian use in West New Britain, Papua New Guinea. In: SHACKLEY M.S. (ed.), Archaeological Obsidian Studies: Method and Theory: 129-158. New York: Springer/Plenum Press.

\section{TORRENCE R.}

1986 Production and Exchange of Stone Tools. Cambridge: Cambridge University Press.

WIESSNER P.

1983 Style and social information in Kalahari San projectile points. American Antiquity 48,2: 253-276.

WRIGHT G.A. and GORDUS A.A.

1969 Source areas for obsidian recovered at Munhata, Beisamoun, Hazaroea and El-Khiam. Israel Exploration Journal 19,2: $79-88$.

YALÇINKAYA I. et OTTE M.

2002 Introduction. In: YALÇINKAYA et al. (éd.): 9-11.

YALÇINKAYA I., OTTE M. et KÖSEM B.

2002 La Grotte d'Öküzini: objets de parure. In : YALÇıNKAYA et al. (éd.): 339-346.

YALÇINKAYA I., OTTE M., KOZLOWSKI J. et BAR-YOSEF O. (éd.)

2002 La Grotte d'Öküzini : Évolution du Paléolithique final du sudouest de l'Anatolie. Liège (ÉRAUL 96).

YELLIN J., LEVY T.E. and ROWAN Y.M.

1996 New evidence on prehistoric trade routes: The obsidian evidence from Gilat, Israel. Journal of Field Archaeology 23,3: 361-368. 